\title{
ACTS OF STATE AND THE FRONTIERS OF PRIVATE (INTERNATIONAL) LAW
}

\author{
Andrew Dickinson \\ * Fellow and Tutor in Law, St Catherine's College and Professor of Law, University of Oxford. Solicitor, \\ England and Wales ${ }^{1}$
}

\begin{abstract}
A growing number of cases before the English courts implicate governmental or sovereign acts with a foreign connection. Cases involving "acts of state" have in the past been bedeviled by legal uncertainty, in terms both of the rationalisation of the common law's approach to them, and the relationship of the rules and principles deployed to the private international law rules ordinarily applied in cases with a cross-border aspect. Three recent decisions of the Supreme Court offer some valuable insights, and a welcome opportunity to take stock and to re-consider the account in the leading modern English commentary.
\end{abstract}

Keywords: act of state; governmental acts; sovereign acts; private law; constitutional law; separation of powers; fundamental rights Brussels I Regulation; Rome I Regulation; Rome II Regulation; civil and commercial matters

\section{Introduction}

From time to time, and with an apparently growing frequency, claims are brought before the English courts which implicate governmental or other sovereign acts with a foreign connection, consisting of acts of a foreign sovereign state or its representatives (wherever done) or acts of the United Kingdom or its representatives done abroad or a combination of the two.

For present purposes, as a starting point for enquiry, the category of "governmental or sovereign acts" can be defined, in a broad sense, as acts whose character is at least in part attributable to the actor's sovereign status or functions. It accommodates, as a minimum, the set of acta iure imperii recognised in public international law, the counterpart of acta iure gestionis in the sense of acts "of a private law character such as a private citizen might have entered into". ${ }^{2}$ The term "implicate" is used here to refer to situations in which the claim is concerned with such acts, including as the foundation of or as an essential element within the cause of action pleaded.

Rules of public international law have only a limited role to play in the determination of such claims. If the defendant is a foreign state $^{3}$ or a foreign state entity ${ }^{4}$ or representative of a foreign state or state entity, or if the interests of a foreign sovereign state or foreign state are indirectly impleaded by the claim, ${ }^{5}$ the law of state immunity (as codified in the State Immunity Act 1978) may require the English court to declare that it has no jurisdiction. However, the State Immunity Act does not apply in other cases, and only rarely applies to claims brought against a person who is not a foreign state, foreign state

1 This article originates in a presentation, on 21 June 2017, at the seminar 'State of Play 2017 Current Issues in Public International Law' organised by Clifford Chance LLP and 20 Essex Street. I am grateful for the comments received from the two anonymous reviewers for this journal, and for having had the opportunity to discuss the topic with Alexander Layton Q.C. and with Bobby Lindsay (University of Glasgow). The usual disclaimer applies.

$2 \quad I^{\circ}$ Congreso del Partido [1983] 1 AC 244, 262, 269 (Lord Wilberforce); Kuwait Airways Corp v Iraqi Airways Co [1995] 1 WLR 1147, 1156-1157 (Lord Goff).

$3 \quad$ State Immunity Act 1978, s 14(1)

$4 \quad$ State Immunity Act 1978, s 14(2).

5 Under s 1(2) of the 1978 Act, a court shall give effect to immunity under the Act even though the state does not appear in the proceedings in question. As s 6(4) makes clear, the scope of the immunity may extend to proceedings against a person other than a state. See $\mathrm{n} 6$ below. 
entity or representative. ${ }^{6}$ Moreover, the Act recognises a number of exceptions to state immunity. ${ }^{7}$ In particular, it provides no impediment to the jurisdiction of an English court in proceedings in which a foreign state or State entity has "submitted to" the court's jurisdiction, whether by bringing proceedings as claimant, by agreement or otherwise. ${ }^{8}$

Private international law plays a more central role in the determination of such claims, and presents a more complex picture. The main causes of this complexity are threefold. First, the implication of governmental or other sovereign acts in the proceedings may take the matter outside the material scope of the legislative instruments adopted by the European Union in the field of private international law (principally, the Brussels I Regulation, ${ }^{9}$ the Rome I Regulation, ${ }^{10}$ and the Rome II Regulation ${ }^{11}$ ) that would ordinarily fall to be applied by the English courts to regulate matters of jurisdiction and the recognition and enforcement of judgments, as well as the law applicable to contractual and noncontractual obligations, in "civil and commercial matters". ${ }^{12}$ Secondly, particularly in cases that are taken outside the material scope of the EU instruments by reason of their subject matter, the implication of governmental or other sovereign acts may equally take the matter outside the scope of the residual (non-EU) rules of private international law applied by the English courts or require those rules to be adapted or supplemented. Consequently, the outcome of a case of this kind and the reasoning giving rise to that outcome may differ fundamentally in comparison with a claim on (perhaps, superficially) similar facts in which a governmental or other sovereign act is not implicated. ${ }^{13}$ Thirdly, in cases that remain within the material scope of the EU private international instruments notwithstanding that a sovereign act has been implicated, it becomes necessary to consider the inter-action of the EU and English legal regimes, and in particular to determine the extent to which the former displaces the latter. $^{14}$

The foregoing propositions may appear somewhat anodyne. Indeed, it would be surprising if the mechanisms within a legal system for the determination of civil claims with a foreign element were "neutral" to pleas concerning acts of a peculiarly State-like character, particularly when those acts are attributed to a foreign state. Nevertheless, a curious researcher or practitioner on first encountering the area would surely be puzzled at the number and variety of legal rules and doctrines invoked in cases of this kind, and challenged by the lack of consensus and certainty among judges, lawyers and commentators as to the character of those rules and doctrines and the relationship between them. Although no doubt acknowledging that the complexity is partly attributable to the many permutations

6 If a foreign state, state entity or representative is not a party to the proceedings, the doctrine of state immunity by impleading will be relevant only in the (very limited) case that the decision in the proceedings would affect any rights or liabilities of the foreign state (see Belhaj v Straw [2017] UKSC 3, [2017] 2 WLR 456, at [12]-[31] (Lord Mance), [181]-[191] (Lord Sumption)).

State Immunity Act 1978, ss 2-11.

State Immunity Act 1978, s 2.

Regulation (EU) No 1215/2012 on jurisdiction and the recognition and enforcement of judgments in civil and commercial matters (recast) [2012] OJ L351/1 (Brussels I Regulation).

10 Regulation (EC) No 593/2008 on the law applicable to contractual obligations (Rome I) [2008] OJ L177/6 (Rome I Regulation).

11 Regulation (EC) No 864/2007 on the law applicable to non-contractual obligations (Rome II) [2007] OJ L199/40 (Rome II Regulation).

12 Brussels I Regulation, Art. 1(1); Rome I Regulation, Art. 1(1); Rome II Regulation, Art. 1(1): see Section III below.

13 See Section IV below.

14 See Section V below.

The impact of the UK's withdrawal from the European Union remains, at the time of writing, uncertain. Nevertheless, the legal basis for applying these instruments will change on the exit date (see the draft European Union (Withdrawal Bill)), thereby altering their relationship to the existing English law rules. 
of fact pattern (in terms of the parties involved, the role played by the sovereign act within the claim and the nature of that act), it is not unlikely that our curious friend would be left with the sense that some further rationalisation and explanation of the law would be advantageous.

Recent Supreme Court decisions offer some valuable insights, and a welcome opportunity to take stock. Although it does not advance a single theory or pretend to offer a satisfactory answer to every question raised, the central theme of this article is that the implication of governmental or other sovereign acts in English court proceedings transports judges to (and sometimes beyond) the edge of private law and into the domain of public law. Entry into the latter introduces a significant constitutional dimension to the case which alters, sometimes fundamentally, the framework within which the matters in dispute fall to be determined. Adjustments to the rules ordinarily applied in cases with a cross-border element are, therefore, best understood for the most part as involving the application of rules of public (including constitutional) law designed or adapted for cases of this kind. So understood, at least some of the complexity that bedevils this area can be rationalised.

The article proceeds as follows. Section II introduces the constitutional aspect of private law. Section III considers the extent to which the EU private international law instruments apply to cases of this kind. Section IV examines the current English law, beginning with the account in the leading modern commentary before examining more closely three recent decisions of the Supreme Court. Section V considers the relationship between EU and English law. Section VI seeks to draw the threads together

\section{The Constitutional Aspect of Private International Law}

Among the first difficulties that a student of the subject commonly taught in our Universities under the title "private international law" or the "conflict of laws" will encounter are problems of terminology and delineation of the subject area. ${ }^{15} \mathrm{He}$ or she will quickly appreciate that neither of the conventional titles quite fulfils the function of describing the topics covered in (or justifying omissions from) the leading texts, and that the boundaries of the subject area and its inter-relationship with other areas of legal study are ill-defined and contested.

These difficulties are inter-connected: the inadequacy of terminology contributing partly to the haziness of subject-definition. The main focus of criticism of "private international law" as a title is on the adjective "international", insofar as it suggests inaccurately that the subject is twinned with public international law. The adjective "private" is, however, also problematic. Although the subject is undoubtedly centred within the province of "private law" (as contrasted with "public law"), and its central focus is upon legal relationships between private actors, the boundaries of this province are neither fixed nor closed and its territory is not exclusive. Private law (however one may choose to define it) is integrated with and relies heavily upon other features of the legal system, including matters that are properly seen as being within the province of public, including constitutional, law.

Whenever a claim before the English courts implicates the governmental or other sovereign act of the United Kingdom or a foreign state, this aspect of the subject comes to the fore. If a sovereign act of the United Kingdom is implicated, the court must analyse the legal consequences of that act within the framework of the UK's (mostly unwritten) constitution. ${ }^{16}$ If a sovereign act of a foreign state is implicated, the court must take account of the prerogative powers of the Crown with respect to foreign relations,${ }^{17}$ as well as to the possibility that the need to decide matters concerning the constitution of

15 Lord Collins of Mapesbury and others (eds), Dicey, Morris \& Collins: The Conflict of Laws (London, 15 ${ }^{\text {th }}$ edn, 2012), [1-088]-[1-089]; A Briggs, The Conflict of Laws (Oxford, $3^{\text {td }}$ edn, 2013), 1-2. The omphaloskepsis is not new (see A V Dicey, The Conflict of Laws (London, $1^{\text {st }}$ edn, 1896), 13-15). 16 R (Miller) v Secretary of State for Exiting the European Union [2017] UKSC 5, [2017] 2 WLR 583, [40]-[46].

${ }_{17} \quad$ Shergill v Khaira [2014] UKSC 33, [2015] AC 359, [40]. 
the foreign state may make the English court a less suitable forum in which to try the action "in the interests of all the parties and the ends of justice". ${ }^{18}$ The relationship of municipal law with public international law also becomes a factor insofar as adjudication by the English court with respect to the lawfulness of state conduct (whether of the UK or a foreign state) arguably encroaches upon mechanisms for resolving questions of responsibility for such conduct at a state-to-state level, whether before the International Court of Justice or via a different dispute resolution mechanism or by means of diplomatic protection. ${ }^{19}$ Accordingly, the court must consider the inter-relationship between private and public law within its own legal system as well as the interfaces with the legal system of at least one other state and the international legal system.

\section{Governmental and other Sovereign Acts in EU Private International Law}

The Brussels I Regulation, Rome I Regulation and Rome II Regulation apply only to "civil and commercial matters". ${ }^{20}$ All contain specific exclusions, inserted for the avoidance of doubt, ${ }^{21}$ of "revenue, customs or administrative matters" and the Brussels I and Rome II Regulation also exclude, again for the avoidance of doubt, "liability of the state for acts and omissions in the exercise of state authority (acta iure imperii)". Here, in giving an autonomous interpretation of the concept of 'civil and commercial matters'. the European Court of Justice has consistently drawn the line in terms of whether the subject matter of the dispute results "from the exercise of public powers by one of the parties to the case, as it exercises powers falling outside the scope of the ordinary legal rules applicable to relationships between private individuals". ${ }^{23}$

Nevertheless, some quite subtle distinctions are in play in defining the frontier between "private" and "non-private" legal relationships. Thus, in Lechouritou v Germany, ${ }^{24}$ a claim founded on the activities of German armed forces in Greece during World War II was held by the European Court to fall outside the Brussels I regime on the basis that "acts such as those which are at the origin of the loss and damage pleaded by the plaintiffs in the main proceedings and, therefore, of the action for damages brought by them before the Greek courts must be regarded as resulting from the exercise of public powers on the part of the state concerned on the date when those acts were perpetrated", notwithstanding that the claim had been pleaded (in accordance with Greek municipal law) as a civil action in tort. ${ }^{25}$ Similarly, in Netherlands State $v$ Rüffer, the fact that the Dutch State had acted in the exercise of its public powers to manage the waterways within its territory when it removed a wreck causing an obstruction was central to the European Court's conclusion that a civil claim to recover the expenses of that removal fell outside the Brussels I regime irrespective of its legal basis under Dutch law. ${ }^{26}$ By contrast, in HM Revenue and Customs v Sunico, a claim by the UK tax authority seeking to recover an amount equal to the amount of tax revenue lost by reason of the defendants' tortious conspiracy was held to fall within the scope of the Brussels I Regulation "since it is common ground that the legal relationship between the Commissioners and Sunico is not governed by United Kingdom VAT law but by the law of tort of that Member State". ${ }^{27}$ According to Advocate General Kokott, in

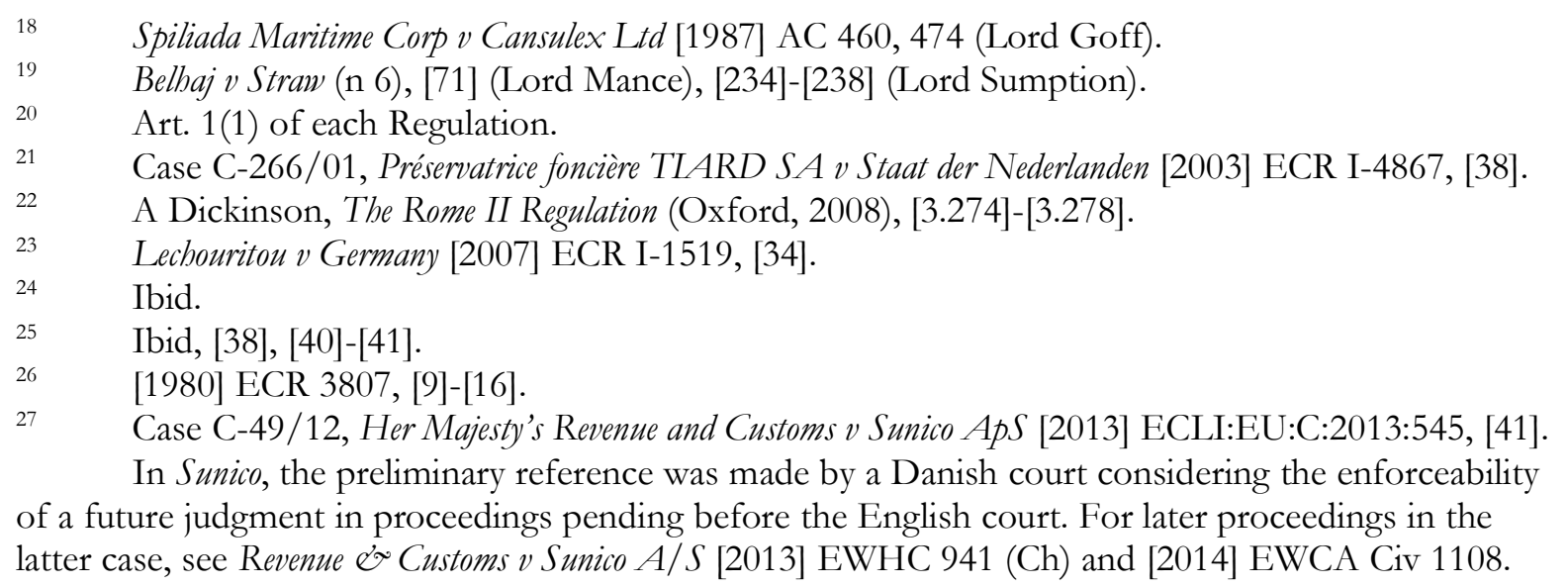


Sunico, the earlier cases could be satisfactorily distinguished, as in Lechouritou and Rüffer "the acts giving rise to the claims were characterised by the exercise of public powers" whereas in Sunico "the underlying facts consist in the alleged fraudulent conduct of the defendants, giving rise to a tortious claim for damages by the state", the claim "is based on an alleged infringement of a legally-protected right by the defendants and hence from an act whose victim can in principle be anyone" and the underlying relationships between the state and taxpayers constituted only the background to the dispute and not its subject matter. ${ }^{28}$ This seems to underplay the fact that the UK's revenue authority sought to recover losses that it had incurred in administering the tax system, by giving credit for VAT paid by the defendants' co-conspirators in the (fraudulently induced) belief that the transaction was genuine and not an artificial device to profit at the expense of the revenue. ${ }^{29}$

An additional complicating factor emerging from the European Court's case law is that a claim may be taken "outside the scope of the ordinary legal rules applicable to relationships between private individuals" if the state is placed in a privileged (or, presumably, underprivileged) position as to matters of procedure or substance. ${ }^{30}$ This is a matter for assessment by the national court, ${ }^{31}$ but again may require some rather fine distinctions to be drawn to answer the question whether the EU private international law instruments apply to a particular case. ${ }^{32}$

IV. Governmental and Other Sovereign Acts in English Private International Law

1. Policing the Borders - Dicey, Morris \& Collins, Rule 3

A first port of call for those undertaking research concerning the English courts' approach to claims implicating governmental or other sovereign acts with a foreign connection would likely be Dicey, Morris and Collins, The Conflict of Laws, now in its 15th edition (2012).$^{33}$ The reader's gaze would quickly fall upon Rule 3, in the following terms:

"English courts have no jurisdiction to entertain an action: (1) for the enforcement, either directly or indirectly, of a penal, revenue or other public law of a foreign state; or (2) founded upon an act of state."

The rule in this form can be traced as far back as the $4^{\text {th }}$ edition of the work, the first edited by Arthur Berriedale Keith, ${ }^{34}$ with the formulation changing little over time. ${ }^{35}$

The relationship between private law and public (tax) law within the English legal system was considered in Revenue and Customs Commissioners v Total Network SL [2008] UKHL 19, [2008] 1 AC 1174. 28 Sunico (n 27), Opinion of Adv Gen Kokott, [47]-[50].

29 cf Case C-102/15, Gazdasági Versenybivatal v Siemens Aktiengesellschaft Österreich, Opinion of Adv

Gen Wahl [2016] ECLI:EU:C:2016:225, [44]-[45]. For a critical comment on the decision in Sunico, see Lord Collins (2014) 130 LQR 353.

30 Sunico (n 27), [42], referring to Opinion of Adv Gen Kokott, [45]. See also TLARD v Netherlands (n 21), [35].

$31 \quad$ See the references in the preceding footnote.

32 See e.g. Joined Cases C-226/13 and others, Fabnenbrook v Hellenic Republic [2015]

ECLI:EU:C:2015:383, [50]-[59], a case concerning Regulation (EC) No 1393/2007 ([2007] OJ L324/79) on the service of documents.

33 Dicey, Morris \& Collins (n 15). The author is one of the specialist editors of that work, but is not responsible for the chapter in which Rule 3 is to be found.

34 Dicey's Conflict of Laws (4 $4^{\text {th }}$ ed., 1932), Rule 54. In the $3^{\text {rd }}$ edition, Rule 54 referred to "a penal or revenue law of a foreign country" only.

35 The first limb of Rule 54 in the $5^{\text {th }}$ edition referred to a "political law" rather than a "public law". The second limb referred in slightly more general terms to a case "where the grounds of the action involve an act of state". 
Presented with this short statement, a curious researcher (armed with a little knowledge of the subject) might be willing to take at face value the description of the Rule as one of "jurisdiction", and to categorise it as a rule restricting the English courts "subject-matter" jurisdiction with respect to cases of the kind identified. Nevertheless, the questions would likely stack up in his or her mind: most obviously, (i) how does one identify "a penal, revenue or other public law of a foreign state", (ii) when is such a law "enforced", "either directly or indirectly", (iii) what is an "act of state", (iv) when is an action "founded upon" such an act, and (v) what is the relationship, if any, between limb (1) (penal etc. laws) and limb (2) (acts of state)?

The following commentary, ${ }^{36}$ while offering considerable assistance in addressing these questions, presents the reader with two more fundamental difficulties.

The first concerns the character and theoretical basis of the Rule. As to its character, the learned editors of Dicey comment as follows: ${ }^{37}$

"Rule 3 is framed in terms of lack of jurisdiction, and it has frequently been cited by the courts, but claims made within the scope of the Rule have usually been dismissed on the merits or been struck out. This was so even in Huntington $v$ Attrill, ${ }^{38}$ where the Privy Council used the terminology of jurisdiction, and which was the principal authority for Rule 3 when it was first formulated. In the eleventh edition of this book it was suggested that it is the foreign state which has no international jurisdiction to enforce its law abroad, and the English court will not exercise its own jurisdiction in aid of an excess of jurisdiction by the foreign state. The substance of this view was adopted in Re State of Norway's Application (Nos 1 and 2), ${ }^{39}$ but in view of its wide acceptance in judicial decisions, Rule 3 has been retained in its traditional form."

As to theoretical basis, the editors suggest ${ }^{40}$ that limb (1), prohibiting the enforcement of foreign penal etc. laws, is best explained on the basis that such enforcement is an extension of sovereign power which imposed the taxes, and that an assertion of such power within the territory of another state is (using the words of Lord Keith of Avonholm in Government of India v Taylor) "contrary to all concepts of independent sovereignties". ${ }^{41}$ On this view, limb (2), insofar as it precludes claims founded on a foreign state's conduct, could be seen as a mirror image of limb (1), precluding the United Kingdom (acting though its judicial branch) from undue interference with the sovereignty of a foreign country. ${ }^{42}$

In Re State of Norway's Application, Lord Goff, referring to the then current edition of Dicey $\left(11^{\text {th }}, 1987\right)$ stated: ${ }^{43}$

"It is not necessary for the purposes of the present case to decide what is the precise theoretical basis of the rule, though I am respectfully inclined to agree with Lord Keith of Avonholm's expression of opinion. At all events the rule cannot, in my view, go to the

See also J Westlake, A Treatise on Private International Law (London, 1880), 175, referring to "political rights".

36 Dicey, Morris \& Collins (n 15), [5-020]ff.

37 Ibid, [5-021] (some references omitted).

$38 \quad$ [1893] AC 150 (PC).

39 [1990] 1 AC 723, 808.

40 Dicey, Morris \& Collins (n 15), [5-020].

$41 \quad$ [1955] AC 491, 511. See also Mbasogo v Logo (n 12), [30]; Shergill v Khaira (n 17), [42].

42 Belhaj v Straw (n 6), [65] (Lord Mance). See Dicey, Morris \& Collins (n 15), [5-046]-[5-047] and the cases there cited.

43 Re State of Norway's Application (n 39), at 808. See also Government of the Islamic Republic of Iran v Barakat Galleries Ltd [2007] EWCA Civ 1374, [2009] QB 22, [97]; Shergill v Khaira (n 17), [41]. 
jurisdiction of the English court. What the English court does is simply to decline in such cases to exercise its jurisdiction, and on that basis the relevant proceedings will be either struck out or dismissed."

Thus, the prevailing orthodoxy would appear to be that (1) the basis of the Rule is to be found in international law doctrines concerning the limits of sovereign jurisdiction, and (2) that it does not exclude the (municipal) jurisdiction of the English courts but leads them to refuse to exercise such jurisdiction as they might otherwise possess.

Neither of these propositions appears satisfactory. As to the first, Peter Carter correctly observed that: ${ }^{44}$

"It is, of course, correct to assert that public international law can place limits upon the entitlement of a State to require that its laws be accorded extra-territorial effect. But what is in a sense the converse of this does not follow. It does not follow that the courts of a State are enjoined by public international law from according effect to laws of another State in excess of that other State's entitlement."

Equally self-evidently, it cannot be said to involve an excess of sovereignty, with a concomitant violation of public international law norms, either (a) for one state to seek assistance from the judicial or executive authorities of another in order to give effect to its laws, or (b) for one state to determine a dispute having a sufficient connection to its territory, even if such determination requires it to examine the conduct of a foreign state abroad or its representative or to apply (or refuse to apply) the laws of that or another foreign state. ${ }^{45}$

As to the second proposition, the idea of "judicial restraint or absention" 46 within the permissible limits of (municipal) jurisdiction appears a remarkably hazy concept. It does not elucidate the nature or function of the restraint. Moreover, to characterise the Rule as being concerned with the exercise of jurisdiction appears to underplay the role that choice of law doctrine has to play in this area. It has long been acknowledged that " $[t]$ he treatment by the courts of measures which effect or authorise an interference by a foreign government with private property rights is based upon the paramount interest of the lex situs in relation to the proprietary effects of a transfer of property". ${ }^{47}$ Moreover, as Professor Briggs has argued, the rule concerning the non-enforcement of revenue laws can also be satisfactorily explained in terms of a choice of law rule, that the lex fori alone governs claims that are characterised as falling into this category ${ }^{48}$ (or, put another way, ${ }^{49}$ that the English courts will only apply revenue laws

44 (1989) CLJ 417, 429. See also A Mills, The Confluence of Public and Private International Law (2009), 228, n. 62.

45 Belhaj v Straw (n 6), [200] (Lord Sumption) (see text to n 193 below). The "sovereignty" argument is addressed in detail, in relation to the non-enforcement of revenue laws, in a Ph.D. thesis undertaken by Niall O'Hanlon, at Trinity College, Dublin, and of which I was an examiner. Reading and examining the thesis has helped to clarify my thinking on this point, and I am grateful to him for this opportunity.

46 Buttes Gas and Oil Co v Hammer (No 3) [1982] AC 888, 934 (Lord Wilberforce).

47 Dicey, Morris \& Collins (n 15), [25-002]. The editors continue "... but it is also sometimes said to be based on the act of state doctrine". See also ibid, [5-047]-[5-048]; Belhaj v Straw (n 6), [35]-[36] (Lord Mance), [229] (Lord Sumption).

48 [2001] Singapore Journal of Legal Studies 280, 295-296. See Government of India v Taylor (n 40), at 514 (Lord Somervell) ("Our courts will apply foreign law if it is the proper law of a contract, the subject of a suit. Tax gathering is not a matter of contract but of authority and administration as between the state and those within its jurisdiction.").

49 Professor Briggs, who emphasises the need to characterise "claims" rather than "rules of law", would not necessarily agree with this reformulation. 
which form part of English law, that is to say those enacted by the Parliament in Westminster ${ }^{50}$ ). These examples give cause to consider whether other aspects of the Rule can be more satisfactorily expressed in terms of the law applicable to the claim before the English court, even if such explanations require the existing choice of law framework to be adapted or supplemented.

The second fundamental difficulty with Rule 3 in its present form concerns the apparent fragmentation in the concept of "act of state". The commentary in Dicey, Morris \& Collins describes a number of (overlapping) cases capable of falling within the apparent scope of the second limb. These include disputes concerning:

- Acts performed by the Crown in the course of its relations with a foreign state. ${ }^{51}$

- The enforcement of rights alleged to be created by such an act which have not yet been incorporated into domestic law. ${ }^{52}$

- Acts which have been authorised or ratified by the Crown in the exercise of sovereign power. ${ }^{53}$

- Acts of foreign governments performed in the course of its relations with another State, or enforcement of rights alleged to have been created by such act. ${ }^{54}$

- Acts of foreign governments within their own territory. ${ }^{55}$

- Foreign legislative acts. ${ }^{56}$

- The transactions of foreign sovereign States. ${ }^{57}$

Accordingly, this limb of the Rule appears to represent little more than a catch-all for circumstances in which the implication in civil proceedings before the English courts of a sovereign act, whether of the United Kingdom or of a foreign state, might result in the English courts approaching the case differently from a case in which an act of that character was not engaged. The unity suggested in the formulation of the Rule is deceptive. ${ }^{58}$ As Lord Reid observed in Nissan v Attormey General, a case concerning governmental acts of the United Kingdom: ${ }^{59}$

"[A] good deal of the trouble has been caused by using the loose phrase 'act of state' without making clear what is meant. Sometimes it seems to be used to denote any act of sovereign power or of high policy or any act done in the execution of a treaty. That is a possible definition, but then it must be observed that there are many such acts which can be the subject of an action in court if they infringe the rights of British subjects. Sometimes it seems to be used to denote acts which cannot be made the subject of inquiry in a British court. But that does not tell us how to distinguish such acts: it is only a name for a class which has still to be defined."

50 The rule can be regarded as being founded in the constitutional principle, enshrined in Art 4 of the Bill of Rights, that there can be no taxation without Parliament (see Woolwich Equitable Building Society v Inland Revenue Commissioners [1993] AC 70, 172 (Lord Goff), 196 (Lord Jauncey); Test Claimants in the FII Group Litigation v Revenue and Customs Commissioners [2012] UKSC 19, [74] (Lord Walker)).

$51 \quad$ Dicey, Morris \& Collins (n 15), [5-043].

52 Ibid.

53 Ibid, [5-044].

$54 \quad$ Ibid, [5-055].

55 Ibid, [5-046].

56 Ibid, [5-048]-[5-050].

57 Ibid, [5-051].

58 As the editors themselves admit in relation to the executive and legislative acts of foreign states (ibid, [5-045]: "The expression [act of state] is found in several contexts, and it may not be possible to extract a general principle which will apply to all of them". See also Belhaj v Straw (n 6), at [33]-[34] (Lord Mance).

59 [1970] AC 179, at 211-212, referred to with approval by Lord Sumption in Belhaj v Straw (n 6), [198]. 
2. "Acts of state" and the Limits of the English Courts' Constitutional Function

Introduction

Having travelled this far, the curious researcher might begin to despair, and be minded to agree with the late Francis Mann (speaking in relation to foreign acts of state) that the doctrine "displays in every respect such uncertainty and confusion and rests on so slippery a basis that its application becomes a matter of speculation". ${ }^{60}$

Although such reactions are understandable, they too readily admit defeat in the quest for greater certainty. Three recent decisions of the Supreme Court offer a measure of clarity, and suggest a way forward.

\section{A Constitutional Framework - Shergill v Khaira}

In Shergill $v$ Khaira, a case which did not concern governmental acts, the Supreme Court suggested a new framework for analysing cases of "non-justiciability", i.e. cases where "an issue is said to be inherently unsuitable for judicial determination by reason only of its subject matter". ${ }^{61}$ In the Court's view, ${ }^{62}$ such cases fall generally (but not exhaustively ${ }^{63}$ ) into one of two categories: first, "cases where the issue in question is beyond the constitutional competence assigned to the courts under our conception of the separation of powers" and, secondly, "claims or defences which are based neither on private legal rights or obligations, nor on reviewable matters of public law". ${ }^{64}$ Examples of the former include the exclusive domain of the executive branch in the field of foreign relations and of Parliament to regulate its own proceedings. ${ }^{65}$ Examples of the latter include claims or defences in civil proceedings which rely on unincorporated treaties and applications for judicial review which lack a "domestic foothold" for the application of public law principles such as a justiciable legitimate expectation or fundamental right. ${ }^{6}$

This framework is unambiguously "constitutional" in its focus. Both categories may be analysed in terms of the doctrine of the separation of powers. The first concerns situations of overlapping constitutional competences, in which priority is given to the competence of the Crown or Parliament over that of the courts. As the Supreme Court noted in Shergill, "[c] ases in this category are rare, and rightly so, for they may result in a denial of justice which could only exceptionally be justified either at

60 F A Mann, Foreign Affairs in English Courts (Oxford, 1986), 164, quoted by Lord Mance in Belhaj v Straw (n 6), [33].

Francis Mann wrote extensively on this subject area. As well as the essays in Foreign Affairs on "The Prerogative in Foreign Affairs" (ch. 1), "Justiciability" (ch. 4), "The Foreign Act of State" (ch. 9) and "The British Act of State" (ch. 10), see Studies in International Law (Oxford, 1973), ch. XI-XIV and Further Studies in International Law (Oxford, 1990), ch. 4 and 14.

${ }^{61} \quad$ Shergill v Khaira (n 17), [41].

62 Ibid, [41]. Lords Neuberger, Sumption and Hodge delivered a judgment with which the other members of the Court agreed.

${ }_{63}$ Belhaj v Straw (n 6), [90] (Lord Mance).

64 Shergill v Khaira (n 17), [42]-[43].

65 Ibid, [42].

66 Ibid, [43], referring to $\mathrm{R}$ (Al-Haq) v Secretary of State for Foreign and Commonwealth Affairs [2009]

EWHC 1910, at [60] (Cranston J). See also JH Rayner (Mincing Lane) Ltd v Department of Trade and Industry [1990] 2 AC 418. The requirement that a treaty be incorporated into law by an Act of Parliament is itself explained in terms of the separation of powers between the Crown and parliament (see $\mathrm{R}$ (Miller) $v$ Secretary of State (n 16), [56]-[57]). 
common law or under article 6 of the [European Convention of Human Rights]". ${ }^{67}$ Such a denial of justice would jeopardise the rule of law. Consistently with this, the exercise by the Crown of its prerogative powers is only exceptionally excluded from judicial review by reference to the subject matter of the enquiry. ${ }^{68}$ The second category, by contrast, concerns the limits of the proper function of the courts within the constitutional framework, as the arbiters of disputes raising questions of private right or recognised public law grounds for reviewing decision making processes. Of course, the two categories are entwined: judicial perceptions as to what matters lie within the "province" of the Crown or Parliament may influence their decisions as to the extent of private rights ${ }^{69}$ or the existence of grounds for judicial review. ${ }^{70}$

\section{(c) Belhaj v Straw and Rahmatullah (No 2) v Ministry of Defence}

More recently, Belhaj v Straw ${ }^{71}$ and Rahmatullah (No 2) v Ministry of Defence, ${ }^{72}$ the Supreme Court was called upon to examine the variety of circumstances that have traditionally attracted the label "act of state", giving it an opportunity to address at least some of the theoretical and practical difficulties encountered above. These two references to the Supreme Court concerned matters arising in a number of actions brought before the English courts in the fallout from the conflicts in Iraq and Afghanistan and the so-called "war on terror". The procedural history is complex. ${ }^{73}$ In each of the four actions involved (Belhaj, ${ }^{74}$ Mohammed v Ministry of Defence ${ }^{75}$ and Rabmatullah (No. 1$)^{76}$ and (No. 2) ${ }^{77}$ ) tortious claims were advanced under foreign law, in accordance with the applicable statutory choice of law rules. ${ }^{78}$ Those claims arose from governmental acts, both of foreign states and of the United Kingdom.

For present purposes, the facts may be briefly summarised. Mr Belhaj and his wife, Mrs Bouchar, both Libyan nationals, claimed that that the six defendants ${ }^{79}$ had been complicit with the Libyan and United States authorities in their abduction, kidnapping, detention and torture. The acts allegedly occurred in a number of foreign jurisdictions ${ }^{80}$ and on board an aircraft registered in the US. Mr Mohammed, an

67 Ibid, [42].

68 Council of the Civil Service Unions v Minister for the Civil Service [1985] AC 374; R (Abbasi) v Secretary of State for Foreign and Commonwealth Affairs [2002] EWCA Civ 1598; [2003] UKHRR 76; R (Bancoult) v Secretary of State for Foreign and Commonwealth Affairs (No 2) [2008] UKHL 61, [2009] 1 AC 453; Rahmatullah (No 2) v Ministry of Defence [2017] UKSC 1, [2017] 2 WLR 287, [15] (Lady Hale), [56] (Lord Mance), [101] (Lord Sumption). See also R (Miller) v Secretary of State (n 16), [3].

${ }_{69} \quad$ For example, the existence of a duty of care in tort (see Barrett v Enfield BC [2001] 2 AC 550, 580-581 (Lord Hutton) and the competing views of the members of the Supreme Court in Smith v Ministry of Defence [2013] UKSC 41, [2014] AC 52).

70 e.g. R (Bancoult) v Secretary of State (n 68), [58] (Lord Hoffmann).

71 n 6 above.

72 n 68 above.

73 A very helpful graphical history appears on the Westlaw UK site.

74 [2013] EWHC 4111 (QB), revd. in part [2014] EWCA Civ 1394.

75 [2014] EWHC 1369 (QB), revd. in part [2015] EWCA Civ 843.

76 [2011] EWHC 2008, revd. [2011] EWCA Civ 1540.

77 [2014] EWHC 3846, affd. [2014] EWHC (QB).

78 Private International Law (Miscellaneous Provisions) Act 1995, Part III. The claims in Belhaj and Rahmatullah fell outside the temporal scope of the Rome II Regulation. Although the claim in Mohammed fell within the temporal scope of the Regulation, it was (correctly - see text to n 170 below) not suggested that the matter was a "civil and commercial matter" within the Regulation's scope (see Section III above).

79 Comprising the Home Office, the Foreign and Commonweath Office, the Attorney General, the Secret Intelligence Service (SIS), the Security Service, an alleged senior official within SIS (Mr Allen) and the former Foreign Secretary, Mr Straw.

80 China, Malaysia, Thailand and Libya. 
Afghan national, brought proceedings against the Ministry of Defence, asserting that he had been wrongfully detained by British armed forces and, subsequently, the Afghan authorities. $\mathrm{Mr}$ Rahmatullah, a Pakistani national, brought proceedings against the Secretary of State for Foreign and Commonwealth Affairs and the Ministry of Defence, asserting that he had been wrongfully detained by British Armed forces in Iraq and that the UK authorities had been complicit in his subsequent detention and alleged mistreatment by the US authorities in Afghanistan (to where he had been transferred).

Before the Supreme Court, it was settled that the claimants would need to establish at trial that the conduct complained of was actionable under the laws applicable in the places where the relevant acts were committed. ${ }^{81}$ No issues of jurisdiction arose other than (in Belhaj) a plea of state immunity on the basis that the foreign states with whom the defendants were said to have conspired were indirectly impleaded.

In both cases, the members of the Supreme Court were unanimous as to the result. In Belhaj (an appeal encompassing also certain aspects of Rabmatullah (No 2)), the Court rejected the submission by the Crown that the proceedings should be dismissed either on the basis of state immunity ${ }^{82}$ or by reason of the implication of the conduct of foreign states. By contrast, in Rahmatullah (encompassing appeals in both cases under that name and in Mohammed), the Court held that the implication of UK government acts done abroad in the conduct of foreign relations provided a sufficient reason why the claims should not proceed to trial.

Unfortunately, the unanimity did not extend to the underlying reasoning. Both decisions suffer from the same structural weaknesses. In each case, Lords Mance and Sumption delivered carefully reasoned and wide-ranging judgments, projecting a particular vision as to how the law in this area could be rationalised. They did not, however, share the same vision: the judgments reveal important differences between them as to the nature, basis and content of the rules and principles under consideration. Even so, had either Justice's vision prevailed, the law would have been left in a more coherent state.

It is, therefore, regrettable that neither Lord Mance nor Lord Sumption managed to carry a majority of colleagues with him on either occasion. In Belhaj, although this part of the judgment of Lord Mance attracted secondary support from Lady Hale and Lord Clarke and that of Lord Sumption garnered the support of Lord Hughes, it was the separate judgment of Lord Neuberger that garnered the support of Lord Wilson, Lady Hale and Lord Clarke, making it the majority judgment. In Rabmatullah, Lord Mance's judgment attracted the support of Lord Hughes, who also concurred with the separate judgments of Lady Hale and Lord Neuberger. Lord Wilson also agreed with Lady Hale. Lord Neuberger agreed on this point with Lady Hale, Lord Mance and Lord Sumption. Lord Clarke agreed that the appeal should be disposed of for the reasons given by all of his colleagues, stating that he did not detect any difference critical to the resolution of the appeal. If a judgment in Rabmatullab is to be regarded as the majority judgment in this case, it is that of Lady Hale.

A further cause for regret is that the judgments of Lord Neuberger in Belhaj and of Lady Hale in Rabmatullah lack the doctrinal clarity of the accounts presented by Lord Mance and Lord Sumption. Lord Neuberger, in particular, appears content to straddle the fence in matters of disagreement between those two Justices. ${ }^{83}$ Lady Hale in Rahmatullah more openly recognises the differences in approach between them and appears to accept the "conceptual advantages" of Lord Mance's

81 Belhaj v Straw (n 6), [5]; Rahmatullab v Ministry of Defence (n 68), [17].

82 See $n 6$ above.

83 Belhaj v Straw (n 6), [151], [167]-[168]. A similar reluctance to commit can be seen in Lordship's judgment in Rahmatullab v Ministry of Defence (n 68), [106], where he agrees with the reasons given by Lady Hale, Lord Mance and Lord Sumption. 
approach..$^{84}$ Nevertheless, far from rejecting Lord Sumption's conflicting approach, the terminology that she uses in expressing her conclusions appears more in alignment with his characterisation of the law. ${ }^{85}$ On this occasion, the coherent development of the law has been impeded by the instinct for judicial collegiality.

With the judgments in the two cases running to more than 170-pages in total, a comprehensive analysis of them is not possible within the confines of this article. Instead, the following commentary will seek to assess the significance of the two decisions in terms of the relationships between private international law, constitutional/public law and public international law in cases of this nature, beginning with the relationship between the so called "act of state doctrine" and public international law before turning to consider the approach in Belhaj $v$ Straw to cases implicating governmental or other sovereign acts of foreign states and the approach in Rahmatullah v Ministry of Justice (No 2) to cases implicating foreign governmental acts of the UK.

\section{(i) The relationship with public international law}

There is a consensus among the members of the Supreme Court in both cases that the rules under consideration are rules of English municipal law, and not rules of public international law. ${ }^{86}$ At the same time, however, the judgments recognise both the influence of international law in shaping English law principles and rules, ${ }^{87}$ and the inherent suitability of some matters for resolution at a state-to-state level. ${ }^{88}$

Foreign acts of state: Belhaj $v$ Straw

The members of the Court in Belhaj are in agreement that a number of distinct, but sometimes overlapping, rules are in play in cases implicating the governmental or other sovereign acts of foreign states. As Lord Mance explains: ${ }^{89}$

"The concept of foreign act of state needs to be disaggregated, or broken down, and approached at a more particular level of enquiry."

Later in his judgment, he reports that "[h]appily there is a very substantial measure of common ground within the Supreme Court about the broad framework or structure of the relevant principles". ${ }^{90}$ Thus, Lords Mance and Neuberger at least are in agreement that it is necessary to isolate a rule (described as a rule of "private international law" ") whereby a foreign state's legislation will normally be recognised and treated as valid insofar as it affects movable or immovable property within the foreign state's jurisdiction. ${ }^{92}$ They also posit, albeit with some hesitation and without deciding, that there exists a second rule, which precludes any investigation into the lawfulness or validity of any "act of a foreign

$84 \quad$ Rahmatullah v Ministry of Defence (n 68), [33].

85 See text to nn 160-161 below.

86 Belhaj v Straw (n 6), [7], [98] (Lord Mance), [151], [168] (Lord Neuberger), [200] (Lord

Sumption) (foreign acts of state); Rahmatullah v Ministry of Defence (n 68), at [2]-[4] (Lady Hale), [50]-[51] (Lord Mance), [89] (Lord Sumption), [102] (Lord Neuberger) (Crown acts). See further text to nn 192193 below.

87 Belhaj v Straw (n 6), [91] (Lord Mance), [120], [151] (Lord Neuberger), [251]-[257] (Lord Sumption); Rahmatullah v Ministry of Defence (n 68), [37], [43] (Lady Hale)

88 Belhaj v Straw (n 6), [43(ii)], [91], [95] (Lord Mance), [123] (Lord Neuberger), [234], [237], [239] (Lord Sumption); Rahmatullah v Ministry of Defence (n 68), [51] (Lord Mance), [88], [95] (Lord Sumption).

89 Belhaj v Straw (n 6), [11(ii)]; also ibid, [227], [239] (Lord Sumption).

$90 \quad$ Ibid, [35].

91 Ibid, [34]-[35] (Lord Mance), [150] (Lord Neuberger), but cf ibid, [229] (Lord Sumption).

92 Ibid, [11(iii)(a)], [35] (Lord Mance), [121] (Lord Neuberger). 
state's executive" (Lord Neuberger ${ }^{93}$ ) or "sovereign act" (Lord Mance ${ }^{94}$ ) but only if the act relates to property situated within the territory of that state at the relevant time. ${ }^{95}$ Neither rule, as so defined, was engaged in Belhaj. ${ }^{96}$

Lord Sumption by contrast subsumes these two rules within a single principle ("municipal law act of state" ${ }^{97}$ ) concerned with the lawfulness of a state's legislative and executive acts within its own territory ${ }^{98}$ and extending to all injurious acts, whether to property or to the person. ${ }^{99}$ In his view, the principle represents a limit on the subject-matter jurisdiction of the English court, ${ }^{100}$ explicable on the basis of the need to respect the sovereignty and autonomy of other states as well as the role of the UK executive in the conduct of foreign affairs. ${ }^{101}$ In his Lordship's opinion, it was engaged in Belhaj with respect to the acts of certain states (Libya, Malaysia, Thailand) within their own territories. ${ }^{102}$

All members of the Court also acknowledge a broader, distinct principle of "judicial restraint or abstention" ${ }^{\prime 103}$ marking out the limits of the matters upon which the English courts will adjudicate, and extending to some (but not all) cases in which the lawfulness or validity of foreign state conduct, whether within or outside the state's own territory, ${ }^{104}$ is implicated in the proceedings. ${ }^{105}$ Lord Mance refers to "issues of a sovereign, international or inter-state nature upon which a domestic court cannot or should not appropriately adjudicate", ${ }^{106}$ Lord Neuberger to "a challenge to the lawfulness of the act of a foreign state which is of such a nature that a municipal judge cannot or ought not rule on it", ${ }^{107}$ and Lord Sumption to a question of "the lawfulness of a state's acts in its dealings with other states and their subjects". ${ }^{108}$ Critically, notwithstanding differences in emphasis and detail between them, there appears to be a consensus, built on the foundations established in Shergill v Khaira, ${ }^{109}$ that this principle is underpinned by constitutional law, fitting within a broader constitutional framework for determining what matters are, or are not, suitable for judicial determination. ${ }^{110}$

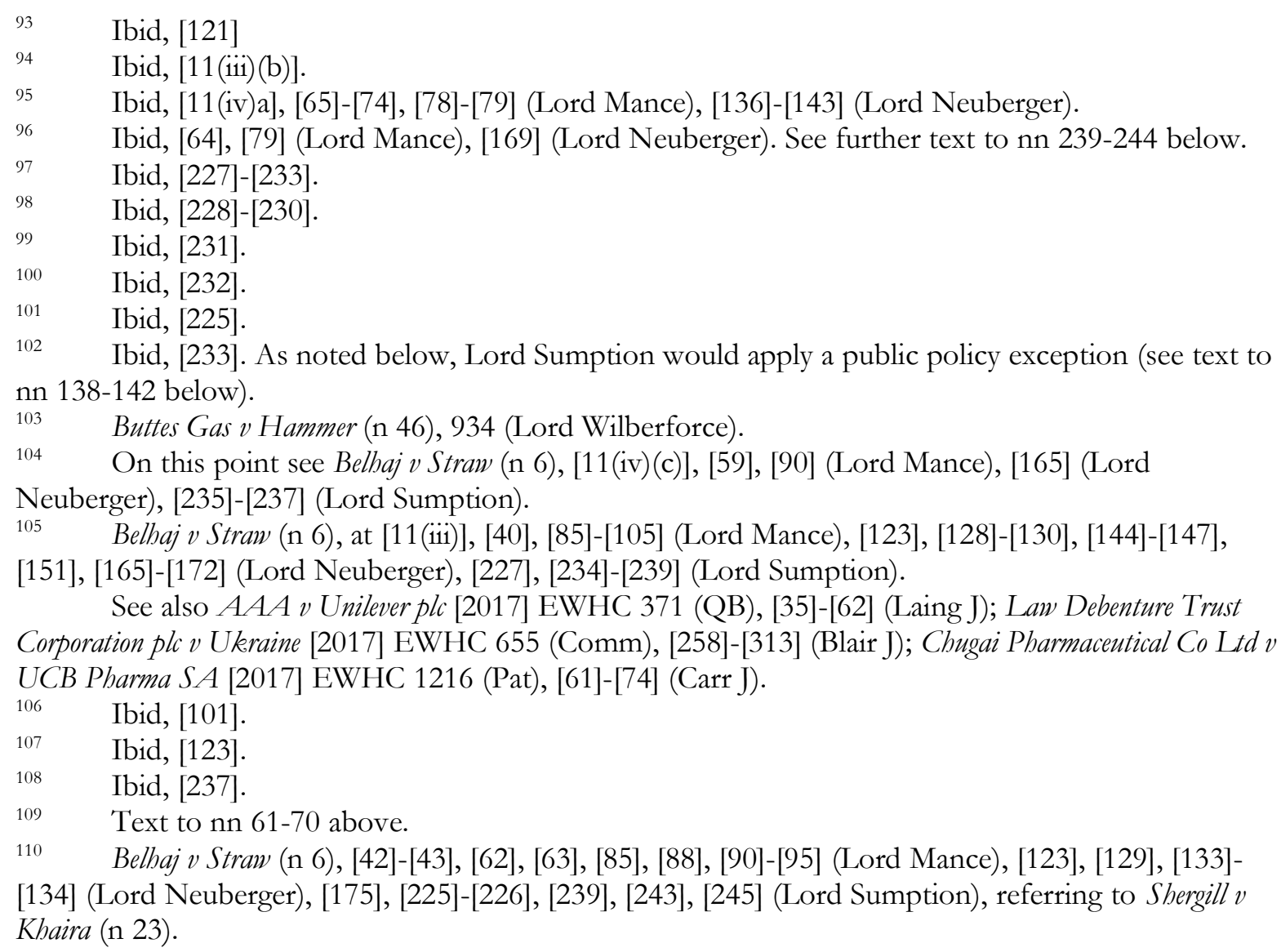


Foremost in this constitutional approach to the implication of foreign state acts is Lord Mance. In his view, the principle has "a broad international basis", ${ }^{111}$ being concerned with avoiding trespass upon "the proper province of the executive, as the organ of the state charged with foreign relations". ${ }^{112}$ For Lord Mance, "[c]onsiderations of separation of powers and of the sovereign nature of foreign sovereign or inter-state activities may both lead to a conclusion that an issue is non-justiciable in a domestic court". ${ }^{113}$ Relying heavily on the reasoning in Shergill $v$ Khaira, ${ }^{114}$ he identifies two broad (nonexhaustive ${ }^{115}$ ) sub-categories of case: first, where an issue in proceedings falls "beyond the constitutional competence assigned to the courts under our conception of the separation of powers" and secondly "of cases not involving private legal rights or obligations or reviewable matters of public policy". ${ }^{116} \mathrm{He}$ emphasises ${ }^{117}$ an important distinction between the two categories that, in the first, the court may not adjudicate on the relevant issue even if it is necessary to decide a matter that unquestionably falls within the court's competence (most obviously, a matter of private right), whereas, in the second, it is necessary to focus on the principal subject matter falling for determination by the court. $^{118}$

Lord Mance also seeks to define the limits of this broader principle by reference to fundamental rights recognised at common law and by statute. In his view: ${ }^{119}$

"Act of state is and remains essentially a domestic law doctrine, and it is English law which sets its limits. English law recognises the existence of fundamental rights, some long-standing, others more recently developed".

Lord Mance includes within this category of "fundamental rights" the prohibition of detention without lawful authority (traceable to the Magna Carta), and the prohibition on torture. ${ }^{120}$ Both rights, as Lord Sumption notes in his own judgment, are embedded in the United Kingdom's constitutional order. ${ }^{121}$ Accordingly, for Lord Mance, the constitutional imperative of protecting fundamental rights must override constitutional impediments to the exercise of adjudicatory authority. ${ }^{122}$

The tortious claims advanced in Belhaj manifestly did not fall within the second sub-category within Lord Mance's framework. ${ }^{123}$ In his Lordship's view, the case also fell outside his first sub-category: although he conceded that "detention overseas as a matter of considered policy" might be a case apart, the allegations of apparently arbitrary detention, transfer and mistreatment in the actions before the court went "far beyond any conduct previously recognised as requiring judicial abstention". ${ }^{124}$

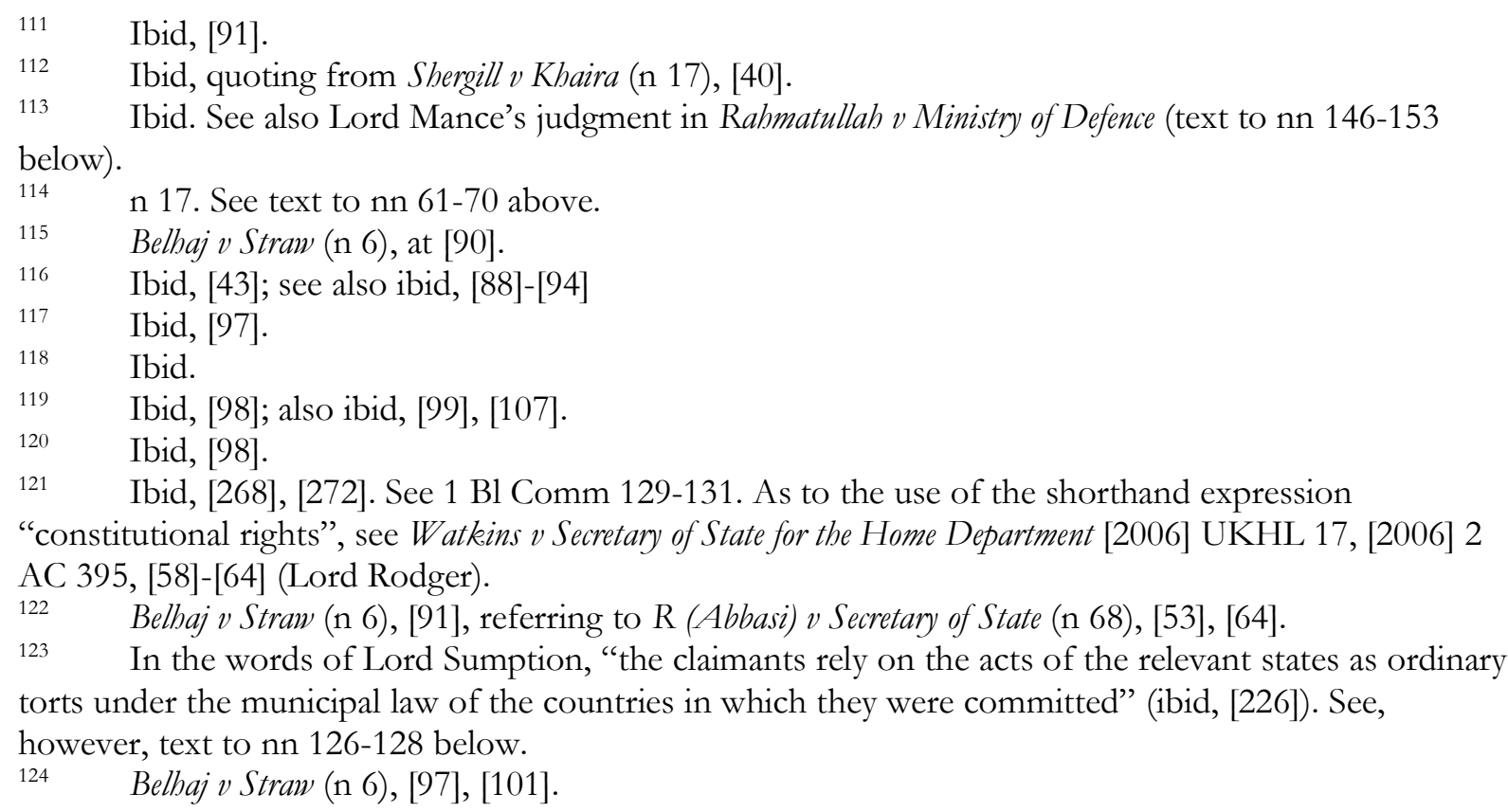


Moreover, in light of the alleged infringements by the relevant foreign states of the claimants' fundamental common law rights not to be arbitrarily detained or tortured, there was in any event "no reason" why the English courts should refrain from scrutinising their conduct in adjudicating claims against defendants over whom they had jurisdiction. ${ }^{125}$

Lord Sumption approaches the matter from a different perspective. Alongside "municipal act of state", he identifies a second principle ("international law act of state") concerned with the transactions of sovereign States. ${ }^{126}$ In his view, judicial restraint is called for in such cases because: ${ }^{127}$

"[O]nce such acts are classified as acts of state, an English court regards them as being done on the plane of international law, and their lawfulness can be judged only by that law. It is not for an English domestic court to apply international law to the relations between states, since it cannot give rise to private rights or obligations. Nor may it subject the sovereign acts of a foreign state to its own rules of municipal law or (by the same token) to the municipal law of a third country. ... If a foreign state deploys force in international space or on the territory of another state, it would be extraordinary for an English court to treat these operations as mere private law torts giving rise to civil liabilities for personal injury, trespass, conversion, and the like."

In his Lordship's opinion, the general principle is that "it is not open to an English court to apply the ordinary law of tort, whether English or foreign, to acts of this kind committed by foreign sovereign states". ${ }^{128}$ If, therefore, a question arises as to the lawfulness of a state's sovereign acts in its dealings with other states and their subjects, Lord Sumption considers that the dispute is carried outside the realm of private law. If we seek to impose Lord Mance's framework for analysing “judicial absention”, Lord Sumption's approach to the case would place it within the second sub-category (i.e. no private right or reviewable matter of public policy).

Nevertheless, Lord Sumption's approach can also be understood in constitutional terms, albeit primarily within the constitutional framework of the international legal order: in his view, it falls outside the courts' "proper function" as an organ of the UK under international law to adjudicate upon the transactions of sovereign states. ${ }^{129}$ Lord Sumption also acknowledges, although not as centrally as Lord Mance, the influence on the doctrine of the separation of powers within the UK's constitution. ${ }^{130}$

Finally, Lord Sumption, like Lord Mance, accepts that his two principles are subject to a limitation on public policy grounds. In his view, fitting with his overall approach, the content of English public policy in this area should be strongly influenced by international law and, in particular, by the characterisation of a particular norm of international law which is alleged to have been violated as one of jus cogens. ${ }^{131}$ In his view, both the prohibition on torture and the prohibitions on arbitrary arrest and detention are of that character. ${ }^{132}$ For good measure, Lord Sumption also identifies the common law's opposition to such conduct as being a matter of "constitutional principle". ${ }^{133}$

In Lord Sumption's view, "it would be contrary to the fundamental requirements of justice administered by an English court to apply the foreign act of state doctrine to an allegation of civil

$\begin{array}{ll}125 & \text { Ibid, [99]-[100], [102]. } \\ 126 & \text { Ibid, [227], [234]-[242]. } \\ 127 & \text { Ibid, [234]. } \\ 128 & \text { Ibid, [237]. } \\ 129 & \text { Ibid, [239]. } \\ 130 & \text { Ibid, [225], [239]. } \\ 131 & \text { Ibid, [252]-[257] } \\ 132 & \text { Ibid, [258]-[278]. } \\ 133 & \text { Ibid, [266]-[272]. }\end{array}$


liability for complicity in acts of torture by foreign states". ${ }^{134}$ This offers a positive reason for judicial intervention which is very similar to that favoured by Lord Mance. ${ }^{135}$ At the same time, Lord Sumption also appears to suggest that the stated justification for the "international law act of state" principle falls away in such a case: "[r]espect for the autonomy of foreign sovereign states, which is the chief rationale of the foreign act of state doctrine, cannot extend to their involvement in torture, because each of them is bound erga omnes and along with the United Kingdom to renounce it as an instrument of national or international policy and to participate in its suppression". ${ }^{136}$ This appears, however, a much more debatable proposition, given that the matter on which the English court is asked to adjudicate is whether the foreign state has engaged in torture (or other internationally wrongful conduct) and Lord Sumption's earlier reasoning appears to emphasise the need for such questions to be addressed exclusively "on the plane of international law" by reference to that law. Moreover, as Lord Mance points out, Lord Sumption's approach "would suggest that a domestic court would be able to adjudicate upon an allegation that its national government connived in a serious violation of the claimant's rights by a foreign government, but would be required to abstain from adjudicating upon a less serious violation, such as 'mere' unlawful detention or cruel or inhuman treatment not amounting to torture". ${ }^{137}$

For Lord Sumption, unlike Lord Mance, the foreign state conduct in issue in the actions before the Court in Belhaj was of a kind that was capable of attracting the broader "act of state" principle requiring judicial restraint. ${ }^{138}$ Lord Neuberger appears (incorrectly) to have considered the two Justices to be at one on this issue, but his reasoning indicates a clear preference for Lord Mance's narrower approach to the scope of the principle. ${ }^{139}$ Nevertheless, reaching the same conclusion as Lord Mance ${ }^{140}$ and Lord Neuberger ${ }^{141}$ for very similar reasons, Lord Sumption concludes that it would not be consistent with English public policy to apply either of the principles that he had identified to prevent the court from determining the allegations of torture, conspiracy to torture and arbitrary detention. ${ }^{142}$

$$
\text { Crown acts of state: Rahmatullab (No 2) v Ministry of Defence }
$$

The different approaches of Lords Mance and Sumption in Belhaj are reflected in their judgments in Rabmatullab concerning claims implicating foreign governmental acts of the UK. For Lord Mance, there exists a single underlying principle of judicial abstention or restraint, which cuts across the categories of foreign and UK "acts of state". ${ }^{143}$ For Lord Sumption, whose municipal and international act of state principles cannot be transposed here, the rule that applies to Crown acts is one of substantive law, under which the executive's authorisation or ratification of the acts serves as a lawful justification of them. In his view: ${ }^{144}$

"The acts of the Crown and its agents are always in principle subject to the adjudicative power of the courts. They unquestionably have both jurisdiction and competence to determine the

\footnotetext{
134 Ibid, [262].

135 Text to nn 119-122 above.

136 Ibid, [262].

137 Ibid, [107(i)].

138 Ibid, [238].

139 Ibid, [167].

140 Text to $n 122$ above.

141 Belhaj v Straw (n 6), [157], [168]-[169], [172].

142 Ibid, [267]-[268], [277].

143 Rahmatullah v Ministry of Defence (n 68), [47], [50].

144 Ibid, [80]. See also ibid, [89], contrasting the exercise of sovereign authority by the Crown and by a foreign state (text to $\mathrm{n} 144$ below). This is an immunity from liability, not an immunity from jurisdiction (cf ibid, [45] (Lady Hale)).
} 
legal effects of a Crown act of state on the rights of those adversely affected by it. The real question is what are those rights."

Notwithstanding this difference in characterisation, there is nevertheless a close affinity between the two Justices' approaches. They concur with Lady Hale's account of the essential characteristics of a "Crown act of state" for this purpose ${ }^{145}$ specifically that the act should be (a) an exercise of sovereign power, inherently governmental in nature, (b) done outside the UK, (c) with the prior authority or subsequent ratification of the Crown, ${ }^{146}$ and (d) in the conduct of the Crown's relations with other states or their subjects. They also agree that the concept extends to the execution, as well as the formulation, of policy decisions. ${ }^{147}$ More fundamentally, Lords Mance and Sumption share the opinion that the underlying principle is one of constitutional law, a principle of consistency closely linked to the doctrine of separation of powers. Lord Sumption, with Lord Mance's approval, expresses that principle as follows: ${ }^{148}$

"The deployment of armed force in the conduct of international relations, or the threat of its deployment (express or implicit) is one of the paradigm functions of the state. The law vests in the Crown the power to conduct the United Kingdom's international relations, including the deployment of armed force in support of its objectives. Constitutionally, as Blackstone observed, the result is that "what is done by the royal authority with regard to foreign powers is the act of the whole nation'."

For Lord Sumption, that principle of constitutional consistency has the following legal consequence: ${ }^{149}$

"In the nature of things, the use of armed force abroad involves acts which would normally be civil wrongs not only under English law but under any system of municipal law. People will be detained or killed. Their property will be damaged or destroyed. It would be incoherent and irrational for the courts to acknowledge the power of the Crown to conduct the United Kingdom's foreign relations and deploy armed force, and at the same time to treat as civil wrongs acts inherent in its exercise of that power."

In his view, the principles that apply to cases implicating the sovereign acts of foreign states are of a different character: in such cases "no question of consistency arises because the sovereign authority of the foreign state is not derived from English law". ${ }^{150}$

By contrast, Lord Mance, reinforcing his reasoning in Belhaj, ${ }^{151}$ considers the difference between the treatment of UK and foreign state acts to be one of degree only: ${ }^{152}$

"Crown act of state is in short based on the same underlying principle of abstention that can in some circumstances also apply to preclude adjudication of the third type of foreign act of

145 Ibid, [37] (Lady Hale), [72] (Lord Mance), [81] (Lord Sumption).

146 On this point, see the contrasting views of Lords Mance and Sumption on the famous, but no longer leading, case of Buron v Denman (1848) 2 Exch 167 (ibid, [66]-[71] (Lord Mance), [83]-[84]).

147 Ibid, [33] (Lady Hale), [73] (Lord Mance), [91] (Lord Sumption).

148 Rabmatullah v Ministry of Defence (n 68), [88] (Lord Sumption); see also ibid, [51] (Lord Mance),

[104] (Lord Neuberger). The quotation from Blackstone is from $1 \mathrm{Bl}$ Comm 245. The quoted passage continues "what is done without the king's concurrence is an act only of private men".

149 Ibid, [88].

150 Ibid, [89].

151 Text to nn 111-122.

152 Rahmatullah v Ministry of Defence (n 68), [51], referring to Belhaj v Straw (n 6), [103]-[105]. 
state. ${ }^{153}$ That is not to suggest that the principle of abstention applies with the same force or by reference to the same considerations in relation to the latter context. ...

Both Crown act of state and the third type of foreign act of state are based on an underlying perception of the role of domestic courts. The constitutional relationship of a domestic court with its own state differs from its relationship with that of any foreign sovereign state."

Moreover, in his view, the principle of consistency also has a role to play in relation to foreign state acts: ${ }^{154}$

"[I]f and when the third type of foreign act of state applies, its underpinning is a more general conception of the role of a domestic court, and, more particularly, the incongruity of a domestic court adjudicating upon the conduct of a foreign sovereign state, even though the foreign state is neither directly or indirectly impleaded or affected in its rights. However, concern for the international relations of the domestic with the foreign state, and in that sense a concern that the domestic court's stance should not be out of line with that of its own state's, may probably in some cases play some part."

Accordingly, in Lord Mance’s opinion: ${ }^{155}$

"These differences in underpinning and analysis between Crown act of state and foreign act of state mean ... that it must be easier to establish that a domestic court should abstain from adjudicating on the basis of Crown act of state than on the basis of the third type of foreign act of state. The relationship is closer and the threshold of sensitivity lower in the case of the former than the latter."

Having referred to limits upon the courts' willingness to subject the exercise of prerogative powers in the foreign policy sphere to public law scrutiny in judicial review proceedings, ${ }^{156}$ Lord Mance notes an "additional parallel aspect at the international level" to support abstention by domestic courts, that "representations and redress in respect of activities involving foreign states and their citizens may be more appropriately pursued at a traditional state-to-state level, rather than by domestic litigation brought by individuals". ${ }^{157}$ This consideration, a weaker version of the reasoning deployed by Lord Sumption in Belhaj to support his 'international law act of state' principle, appears to play only a subordinate role within Lord Mance's framework. ${ }^{158}$

Lady Hale acknowleges "conceptual advantages" in the "non-justiciability" (i.e. judicial abstention) approach favoured by Lord Mance. ${ }^{159}$ In her subsequent reasoning and conclusions, however, she refers repeatedly to the "doctrine of act of state" as a "defence" 160 and "a rule of the substantive law", 161 suggesting a preference for Lord Sumption's characterisation.

153 Lord Mance cross-refers at this point to his judgment in Belhaj v Straw (text to nn 111-122 above).

154 Rabmatullah v Ministry of Defence (n 68), [51].

155 Ibid, [52].

156 Ibid, [56], referring to Council of Civil Service Unions v Minister for the Civil Service [1985] AC 374, 418 (Lord Roskill) and to R (Bancoult) v Secretary of State (n 68).

157 Ibid, [57].

158 Text to nn 127-130 above.

159 Ibid, [33].

160 Ibid, [34], [35], [37], [38]-[40], [42]-[45].

161 Ibid, [45]. In rejecting any role for Art 6 of the ECHR, Lord Mance also appears to characterise his approach as one of substantive law (ibid, [76]), but it appears that this statement must be understood in context as a reference to substantive constitutional law. 
In her judgment, Lady Hale also addresses the relationship of the "Crown act of state" doctrine to the regime for establishing the law applicable to claims in tort under Part III of the Private International Law (Miscellaneous Provisions) Act 1995. She suggests that the non-application of the otherwise applicable foreign law can be supported on the basis of "public policy", within s 14(3)(a) of the Act. ${ }^{162}$ A better explanation, more consistent with Lady Hale's explanation that "the courts of this country will apply the domestic doctrine of act of state rather than the tort law of the state where the events took place" 163 would be that the substantive "defence" (or justification) available under English law that Lord Sumption and Lady Hale identify is given overriding effect under s 14(4) of the 1995 Act.

Putting aside these differences in reasoning, the members of the Court agreed that the claims before them in Rabmatullab were within the limits of the doctrine, and that the actions should not proceed to trial. ${ }^{164}$ Significantly, the claims which the defendants sought to bar (in contrast with those before the court in Belhaj ${ }^{165}$ ) did not involve allegations of torture or of mistreatment in custody. Had they done so, there are indications (albeit obiter) that the case would have been decided differently. Lord Sumption suggested that: ${ }^{160}$

"Given the strength of the English public policy on the subject, a decision by the United Kingdom government to authorise or ratify torture or maltreatment would not as a matter of domestic English law be a lawful exercise of the royal prerogative. It could not therefore be an act of state. Nor would there be any inconsistency with the proper functions of the executive in treating it as giving rise to civil liability."

Lord Mance, on the other hand, appeared to question the utility of the word "lawful" in this context. ${ }^{167}$ In his view, no doubt, any restriction of the principle of judicial abstention that he would favour in such cases could be explained on the basis of the overriding constitutional force of fundamental human rights recognised at common law and by statute. ${ }^{168}$

\section{Appraisal}

This area of the law is in better shape following the Supreme Court's decisions in Belhaj v Straw and Rabmatullab (No 2) v Ministry of Defence, even if some uncertainty remains as to its contours. The emphasis, in particular by Lord Mance, of the constitutional dimension is particularly valuable in enabling the rules and principles described to be understood in their proper legal context, as the crossborder aspect of municipal constitutional or public law, rather than as mutated or attenuated forms of rules of private international law or public international law. The Supreme Court's judgments are valuable also for their synthesis of the distinct rules and principles that apply to claims implicating sovereign acts of foreign states, and analysis of their relationship with the category of claims implicating foreign sovereign acts of the UK.

V. The inter-action of English and EU Law

In Belhaj, the Supreme Court made only passing reference to the Brussels I Regulation, and no reference at all to the Rome II Regulation concerning the law applicable to non-contractual

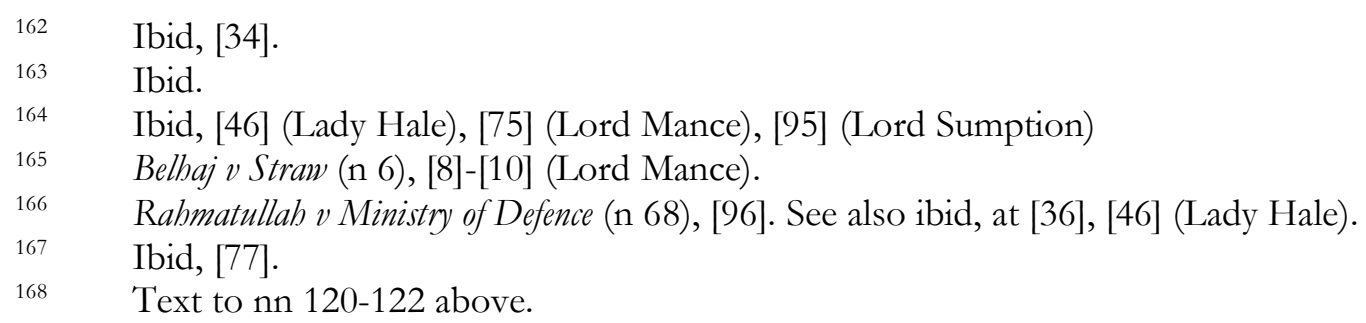


obligations. ${ }^{169}$ Neither Regulation was referred to in Rabmatullab (No 2). There appears to have been no attempt to argue in either case that these Regulations applied to determine the courts' jurisdiction or the law applicable to the claims. Aside from the fact that much of the conduct complained of occurred before 11 January 2009, falling outside the temporal scope of the Rome II Regulation, the defendants were all organs or representatives of the UK and were sued in respect of the exercise of their functions within the UK's foreign ministry or security services. Accordingly, although the claims were formulated by reference to rules of foreign tort law that likely apply also to relationships between private individuals, the European Court's reasoning in Lechouritou v Germany ${ }^{170}$ supports the conclusion that these claims fell outside the material scope of the two Regulations.

Accordingly, the Supreme Court did not need to address any questions concerning inter-relationship of the common law's "act of state" doctrine with the EU's private international law instruments. If the implication of a governmental or other sovereign act, coupled with the joinder of a state party, takes the subject matter of the proceedings outside the material scope of the relevant EU legislative instruments, the English doctrine can operate independently.

In other cases, however, the subject matter of proceedings may be characterised as "civil and commercial", and within the material scope of the EU instruments, notwithstanding that a governmental or other sovereign act is in some sense "in play". A recent example is The Law Debenture Trust Corporation plc v Ukraine in which the Rome I Regulation was held to apply to determine the law applicable to the question of whether a contract was voidable for duress. ${ }^{171}$ The court nevertheless held that it was required, in accordance with the principles laid down in Belhaj, to abstain from adjudicating upon the conduct of the Russian Federation relied on by Ukraine in support of its plea of duress. ${ }^{172} \mathrm{~A}$ claim solely between private parties (for example, of the kind advanced in Buttes Gas v Hammer ${ }^{173}$ ) will also constitute a "civil and commercial matter" even if the exercise of public powers by a non-party is implicated. ${ }^{174}$

Other examples involve the first limb of Dicey's Rule 3. ${ }^{175}$ In QRS1 ApS v Frandsen ${ }^{176}$ and Mbasogo v Logo $L t d,{ }^{177}$ claims were brought (in the first case, by a company liquidator; in the second case, by the Republic of Equatorial Guinea and its President) that were considered to fall within the scope of the common law prohibition on the enforcement of the penal, revenue or other public laws of a foreign state. ${ }^{178}$ The claims were dismissed on that basis. Nevertheless, it was a notable fact that the sole

\footnotetext{
169 Belhaj v Straw (n 6), [36], [43] (Lord Mance).

170 nn 23-25.

171 Law Debenture v Ukraine (n 105), [175] (Blair J).

172 Ibid, [258]-[313].

$173 \mathrm{n} 46$.

174 See text to n 23 above; also Case C-420/07, Apostolides v Orams [2009] ECR I-3571, [45].

175 Section IV.1 above.

176 [1999] 1 WLR 2169.

177 [2006] EWCA Civ 1370, [2007] QB 846.

178 In QRS1 v Frandsen (n 176), this proposition was common ground between the parties, who were content to rest on the (highly questionable) authority of the Irish High Court's decision in Peter Buchanan Ltd v McVey [1955] AC 516 (note). In Mbasogo v Logo (n 177), the Court of Appeal defined the category of "public laws" by reference to "whether in bringing a claim, a claimant is doing an act which is of a sovereign character or which is done by virtue of sovereign authority; and whether the claim involves the exercise or assertion of a sovereign right" (ibid, [50]). See further $n 181$ below.

See also Government of the Islamic Republic of Iran v Barakat Galleries Ltd (n 43), in which the Republic's claim was held to be founded on a patrimonial right and not to be a claim involving the assertion of a sovereign right. The Court noted in passing (ibid, [126]) that the distinction "bears some relationship" to the test adopted by the European Court in defining the concept of "civil and
} 
defendant in QRS1 and a number of the defendants in Mbasogo were domiciled within the EU, potentially bringing the rules of jurisdiction within the Brussels I regime into focus. In QRS1, the Court of Appeal held that the Brussels Convention (the predecessor to the Regulation) did not apply to a claim to recover lost tax revenue by means of a private law action. That conclusion can no longer sit comfortably with the European Court's reasoning in HM Revenue and Customs v Sunico. ${ }^{179}$ Similarly, although the point was not taken in Mbasogo, it seems questionable in light of Sunico whether the fact that the claimants sought to recover costs incurred in the exercise of governmental functions (a factor critical to the Court of Appeal's reasoning in that case ${ }^{180}$ ) would take a claim founded on the English tort of conspiracy to injure outside the scope of the Brussels I regime. ${ }^{181}$

In cases of this kind, there is undoubtedly a potential dissonance between EU and English law. The European Court has held that the rules of private international law contained in the relevant EU legislative instruments are mandatory and exhaustive in character ${ }^{182}$ Furthermore, the principle of effectiveness in EU law operates to restrain the application of rules of domestic law if their application would be such as to make the application of a relevant provision of EU law impossible or excessively difficult, even though the domestic rules in question may be of a different character to those harmonised by EU law. ${ }^{183}$

In QRS1, the Court of Appeal expressed the opinion (obiter) that the prohibition on the enforcement of foreign revenue laws in Dicey's Rule 3 was incompatible with the EU rules governing jurisdiction in civil and commercial matters, to the extent that both were engaged: ${ }^{184}$

"The necessary corollary of rule 3 of Dicey \& Morris is that any such claim as this can only properly be brought in the tax authority's own courts. Were the [Brussels] Convention to apply, rule 3 would seem to me not merely to impair its effectiveness but indeed substantially to derogate from it."

The question of compatibility of EU and English law arose once more in Lucasfilm v Ainsworth. ${ }^{185}$ In that case, a claim for infringement of a foreign copyright was held by the Supreme Court to fall outside the

commercial matter" in the Brussels I Regulation, without investigating that relationship in further detail.

179 Text to nn 26-28 above.

$180 \quad$ Mbasogo v Logo (n 177), [54]-[67].

181 The Court of Appeal was prepared to accept (ibid, [27], [55]) that, if the claimants had sought to bring a tortious claim for compensation for an invasion of their property rights, that action could have proceeded to trial. Nevertheless, the fact of the defendants' participation in an attempted coup d'etat against the claimants' interests may provide an alternative (and better) argument for distinguishing their entire relationship from one between private individuals, taking even a property-based claim outside the scope of the Brussels I regime. cf. Attorney General (UK) v Henemann Publishers Australia Pty Ltd (1988) 165 CLR 30.

182 Case C-281/02, Owusu v Jackson [2005] ECR I-1383, [37] (Brussels I Regulation); Case C135/15, Republik Griechenland v Nikiforidis [2016] ECLI:EU:C:2016:774, [49]-[50] (Rome I Regulation).

183 See, in relation to the Brussels I Regulation, Case 288/82, Duijnstee v Goderbauer [1983] ECR 3363, [13]; Case C-365/88, Kongress Agentur Hagen GmbH v Zeehaghe [1990] ECR I-1860, [20]; Case C159/02, Turner v Grovit [2004] ECR I-3565, [29]; Case C-375/13, Kolassa v Barclays Bank plc [2015] ECLI:EU:C:2015:37, [60].

$184 \quad$ QRS1 v Frandsen (n 176), 2178. See also Goldman Sachs International v Novo Banco SA [2015] EWHC 2371 (Comm), [112] (Hamblen J) (revd. sub nom Guardians of New Zealand Superannuation Fund v Novo Banco SA [2016] EWCA Civ 1092 without addressing this point). 185 [2011] UKSC 39, [2012] 1 AC 208. See also Pearce v Ove Arup [1997] Ch 293 (Lloyd J) and [2000] Ch 403 (CA) (text to nn 195, 202, 206 below). 
scope the "act of state" doctrine. ${ }^{186}$ Indeed, the majority were sceptical whether any action for infringement of foreign intellectual property rights would properly fall within the scope of that doctrine, even if validity of the right were in issue ${ }^{187}$. Nevertheless, the Court expressed (obiter) a significant doubt as to whether the Brussels I Regulation required the English court to exercise jurisdiction as against an EU domiciled defendant in every case falling within the Regulation's scope, regardless of its subject matter. Faced with the claimant's argument to this effect, founded upon the European Court's decision in Owusu v Jackson, Lords Collins and Walker suggested as follows: ${ }^{188}$

"Although in argument it was stressed that the argument was one of lack of jurisdiction rather than non-justiciability, in substance the real point of the argument is that if [the claimant] were right, then the Brussels I Regulation would require the English court to adjudicate on other matters which have hitherto been regarded as non-justiciable, such as 'the transactions of foreign sovereign states'; ${ }^{189}$ and that to require the English court to so adjudicate would be contrary to international law (or, perhaps more accurately, put the United Kingdom in breach of international law)."

The current edition of Dicey, Morris \& Collins is more emphatic insofar as it suggests that "the principle in Owusu v Jackson does not affect the rules relating to matters which have hitherto been regarded as non-justiciable". ${ }^{190}$ No authority other than Lucasfilm is given in support of that proposition.

With respect, this reasoning is flawed. First, although EU legislative instruments must be interpreted in a manner that is consistent with generally accepted principles of international law, ${ }^{191}$ it is not - as the Supreme Court's decisions in Belhaj and Rahmatullah make clear - contrary to any rule of public international law for the English courts to determine questions as to the lawfulness or validity of governmental or sovereign acts (whether of a foreign state or of the UK) in proceedings in which private law rights are in issue. ${ }^{192}$ Even Lord Sumption, whose approach in Belhaj relies most heavily on international law, acknowledges that: ${ }^{193}$

"Although international law requires states to respect the immunity of other states from their domestic jurisdiction, it does not require them to apply any particular limitation on their subject matter jurisdiction in litigation to which foreign states are not parties and in which they are not indirectly impleaded. The foreign act of state doctrine is at best permitted by international law. It is not based upon it."

Secondly, the argument that a requirement to exercise jurisdiction would be incompatible with international law could not in any event extend to a case in which the relevant state had given its consent. That would include a case such as Mbasogo $v \operatorname{Logo}^{194}$ in which the foreign state in question had sought an adjudication of the relevant subject-matter by instituting proceedings. Such consent could also be derived from an international treaty, most obviously for present purposes from a state's

186 Ibid, [65]-[68], [81]-[86], [107]

187 Ibid, [86], but compare ibid, [115] (Lord Mance) and see Chugai Pharmaceutical Co Ltd v UCB

Pharma (n 105), esp at [61]-[74] (Carr J).

188 Ibid, [112].

189 Lord Walker and Lord Collins referred at this point to Buttes Gas v Hammer (n 46), 931.

190 Dicey, Morris \& Collins (n 15), [5-053].

191 See e.g. Case C-154/11, Mahamdia v People's Democratic Republic of Algeria [2012]

ECLI:EU:C:2012:491, [53]-[56]; Case C-466/11, Currà v Bundesrepublik Deutschland [2012]

ECLI:EU:C:2012:465, [18].

192 Section IV.2(c)(i)-(ii) above. As to the limited role played by the doctrine of state immunity, see text to $\mathrm{nn}$ 4-8 above.

193 Belhaj v Straw (n 6), [200].

194 n 178. 
membership of the European Union and participation in the adoption of the Brussels I Regulation allocating civil jurisdiction among the courts of the Member States in civil and commercial matters. ${ }^{195}$

If the rationalisation based on international law is discarded, two critical questions present themselves. First, is the rule of English law relied on of such a character that its application is excluded in terms by the relevant EU instrument? Secondly, assuming a negative answer to the first question, does the application of the rule of English law relied on nevertheless make it impossible or excessively difficult to apply any relevant provision within an EU legislative instrument, so as to engage the principle of effectiveness? As to the first question, although the characterisation of a rule under national (here, English) law cannot be determinative, ${ }^{196}$ it is helpful to understand the function that the rule is considered to serve within the legal system that applies it. In Belhaj, Lord Mance prefers to describe the broader principle applied to foreign acts of state as one of "judicial abstention", ${ }_{197}$ Lord Neuberger as one of "judicial self-restraint" 198 and Lord Sumption as "a subject matter immunity". ${ }^{199}$ Although, no doubt, this principle serves to restrict the matters over which the English court will exercise jurisdiction, it does appear to be of a different character to the rule within the Regulation (Art 27) which requires Member State courts to decline jurisdiction on the basis of the subject-matter of the proceedings. The latter rule operates on the basis that another Member State court has exclusive jurisdiction over the subject-matter, ${ }^{200}$ whereas this aspect of the "act of state" doctrine appears to function on the basis that the lawfulness or validity of matters concerning the conduct of one State towards another State or its subjects is a matter to be settled at a political or inter-State level and not by judicial proceedings. ${ }^{201}$ On this analysis, it seems something of a stretch to argue that this principle is among "the rules of national jurisdiction" that are excluded by Art 5(2) of the Brussels I Regulation in a case in which the defendant is domiciled in a Member State. ${ }^{202}$

195 This argument found favour with the Court of Appeal in Pearce $v$ Ove Arup (n 185) in concluding (at 432, 436) that a state's participation in the 1968 Brussels Convention (the predecessor to the Brussels I Regulation) overcame any argument that claims for trespass to foreign land or infringement of intellectual property rights falling outside the narrow categories of "exclusive jurisdiction" in Art 16 of the Convention were not justiciable before the English courts (see now Regulation, Art 24). See also Lucasfilm v Ainsworth (n 185), [98], discussed below text to nn 233-234.

196 Turner v Grovit (n 183), [26]-[28].

197 Belhaj v Straw (n 6), [91].

198 Ibid, [151].

199 Ibid, [200]. Lord Mance (ibid) and Lord Sumption (ibid, [239]) eschew the language of "nonjusticiability".

200 Brussels I Regulation, Art 24. See also Recital (24), $2^{\text {nd }}$ para, with respect to the discretionary provisions concerning proceedings before non-Member State courts in Arts 33 and 34.

201 Belhaj v Straw (n 6), [95] (Lord Mance), [129] (Lord Neuberger), [234], [237], [239] (Lord Sumption). See also Shergill v Khaira (n 17), [41].

202 Pearce v Ove Arup Partnership Ltd (n 185), 305, 308 (Lloyd J), distinguishing the so called 'Moçambique rule' (which, in his view, was incompatible with the 1968 Brussels Convention) from "other exclusionary, rules such as acts of state" (not incompatible) because the former - but not the latter "proceed on the clear premise that the English courts are not a suitable forum for such an action whereas the courts of another country are appropriate". That distinction between the Mocambique rule and the "act of state" doctrine now seems much less clear following the Supreme Court's decision in Lucasfilm (see text to nn 223-234 below).

Note also, in relation to the doctrine of state immunity, Lechouritou (n 23), Opinion of Adv Gen Mengozzi, [77], drawing a distinction between rules of 'competence' and of 'jurisdiction', the latter, regulated by the Brussels I regime, delimiting the former, apparently outside it. As the doctrine of state immunity applies (in principle) universally as a matter of customary international law, this case law is of very limited assistance in the present context. 
The conclusion that there is no incompatibility in terms between the EU Regulations and the English law is more easily reached in relation to "Crown acts of state", as considered in Rahmatullah. The predominant view (of Lord Sumption and Lady Hale) would appear to be that the doctrine operates substantively, displacing the otherwise applicable rules of foreign law. ${ }^{203}$ On this view, the potential incompatibility is not with the Brussels I Regulation but rather with the Rome II Regulation, and Art 16 of the latter Regulation, which enables Member State courts to apply overriding mandatory provisions of the law of the forum, should enable any such conflict to be avoided. ${ }^{204}$

Similarly, to the extent that claims implicating "foreign acts of state" are controlled by means of choice of law rules, which determine the cases to which the law of the relevant foreign state will apply and those to which it will not, ${ }^{205}$ there appears no obvious possibility of a direct incompatibility with the rules of the Brussels I Regulation (which are of a different character ${ }^{206}$ ) or the Rome I or Rome II Regulation (which apply only to contractual and non-contractual obligations).

Turning to the second question, involving principle of effectiveness, it must first be noted that this principle has effect in EU law notwithstanding that the rule applied within a Member State's legal system whose application is said to interfere with the relevant EU legislative instrument is a rule of municipal constitutional law. ${ }^{207}$ Accordingly, the constitutional underpinning of the rules principles applied by the English courts to cases implicating governmental or other sovereign acts, as identified in Belhaj and Rahmatullah, does not immunise them from scrutiny on this ground.

The argument that at least some elements of the English legal system's treatment of claims implicating governmental or sovereign acts make it impossible or excessively difficulty to apply rules within the EU's private international law instruments and, as such fall foul of the principle of effectiveness, seems much stronger than the argument based on direct (in terms) incompatibility. ${ }^{208}$ With respect to the relationship between the Brussels I Regulation and the principle of judicial restraint applied by the English court in cases implicating foreign acts of state, ${ }^{209}$ the argument that the principle of effectiveness is engaged may be formulated as follows: (1) the EU has established in that Regulation a set of harmonised rules for matters of jurisdiction and the recognition and enforcement of judgments in civil and commercial matters, (2) as the European Court has made clear, the expression 'civil and commercial matters' is to be given an autonomous meaning, independent of the law of the States concerned, ${ }^{210}$ (3) within its subject matter limits, the Regulation draws no distinction between 'personal jurisdiction' and 'subject matter jurisdiction', ${ }^{211}$ (4) as to matters of jurisdiction, the Regulation lays down "common rules of jurisdiction" when the defendant is domiciled in a Member State, ${ }^{212}$ (5) those

Text to nn 160-163.

204 There seems little doubt that the English law rule, given its basis in constitutional law (Section IV.2(c)(iii) above), falls within the category of "overriding mandatory provisions" (cf Case C-184/12, United Antwerp Maritime Agencies NV v Navigation Maritime Bulgare [2013] ECLI:EU:C:2013:663, [47], [48], [52]).

205 Text to nn 47-50, 90-95 above.

206 cf Pearce v Ove Arup (n 185), in which Lloyd J, at first instance, concluded (at 308) that the common law 'double actionability' rule for tort was a 'measure having an equivalent' effect to a rule of jurisdiction, and was as such inconsistent with the mandatory effect of the 1968 Brussels Convention. 207 Case C-399/11, Melloni v Ministerio Fiscal [2013] ECLI:EU:C:2013:107, [59] ("rules of national law, even of a constitutional order, cannot be allowed to undermine the effectiveness of EU law on the territory of that state"). cf the qualifications within TEU, Art 4(2) and TFEU, Art 67(1).

208 cf Pearce v Ove Arup (n 185), 305, 308 (Lloyd J), where the two arguments are blurred.

209 Section IV.2(c)(ii) above.

210 Lechouritou (n 23), [29].

211 A Dickinson [2010] LMCLQ 181, 184-185, challenging the contrary assertion by the Court of Appeal in Lucasfilm v Ainsworth [2009] EWCA Civ 1328, [2012] Ch 503, [129].

212 Brussels I Regulation, Recital (13). 
rules are designed to be "highly predictable and founded on the principle that jurisdiction is generally based on the defendant's domicile", ${ }^{213}$ a principle that exists for the protection of both the defendant and the claimant, ${ }^{214}(6)$ jurisdiction "should always be available on this ground save in a few welldefined situations in which the subject-matter of the parties or the autonomy of the parties warrants a different connecting factor", ${ }^{215}$ (7) as to the recognition and enforcement of judgments, a judgment given by the courts of a Member State is to be treated for this purpose "as if it had been given in the Member State addressed", ${ }^{216}$ (8) the principle of English law described in Belhaj v Straw, insofar as it requires the English courts to refrain from exercising their Regulation-based jurisdiction for a reason relating to the subject matter of the action (i.e. the implication of a sovereign act), (i) undermines the autonomous definition of 'civil and commercial matters' by treating some matters of this character as being incapable of being determined by judicial proceedings, (ii) creates an imbalance in the set of harmonised rules allocating jurisdiction between the courts of the Member States by a unilateral selfdenying principle ${ }^{217}$ of uncertain scope, ${ }^{218}$ and (iii) deprives the claimant of the legal protection afforded to him by the Regulation, of suing in the court's of the defendant's domicile, ${ }^{219}$ (9) insofar as the English law principle may also require the English courts to decline to recognise or enforce a judgment given by another Member State court in such a matter on account of its subject matter, ${ }^{220}$ it restricts the free movement of judgments within the EU, and that restriction must be justified on one of the grounds set out in Art 45 of the Regulation, and (10) although it might be possible in the latter context to invoke the public policy exception in Art 45(1)(a) to justify the application of the English law "act of state" principle, ${ }^{221}$ or to rely on the residual category of national grounds for refusal of enforcement in Art 41(2), no equivalent exception exists within the rules governing jurisdiction. ${ }^{222}$

213 Ibid, Recital (15) and Art 4. By contrast, if the defendant is not domiciled in a Member State, Art 6 delegates the question of jurisdiction to the forum's own rules of jurisdiction.

214 Owusu v Jackson (n 182), [39]-[42].

215 Brussels I Regulation, Recital (15).

216 Ibid, Recital (26).

217 Owusu v Jackson (n 182), [44].

218 Ibid, [43].

219 See Case C-94/14, Flight Refund v Deutsche Lufthansa AG [2016] ECLI:EU:C:2016:148, [66]. 220 English law approaches cases falling within limb (1) of Dicey's Rule 3 on the basis that "the essential nature and real foundation of a cause of action are not changed by recovering judgment upon it" (Dicey, Morris \& Collins (n 15), [5-028] referring to Wisconsin v Pelican Insurance Co Ltd, 127 US 265, 292 (1888)). A foreign judgment based on a penal etc. law is thus no more actionable before an English court than the underlying claim. Although there is a fresh cause of action (the obligation arising under the judgment), the approach seems correct in principle: the foreign proceeding does not shed its "public law" skin by reason of the act of giving judgment.

Similar reasoning may apply to foreign judgments concerning matters falling within limb (2) ("act of state") on the basis that the English court's recognition of a foreign judgment, giving its reasoning the status of res judicata within the English legal system, may be seen as falling outside the limits of the court's constitutional function. This must depend, as Lord Mance emphasised in Belhaj v Straw (n 6), [90], on a case-by-case analysis in light of the issues involved.

221 Although mere political considerations or foreign relations concerns cannot suffice (Apostolides $v$ Orams (n 174), Opinion of Adv Gen Kokott, [110]; Apostolides v Orams [2010] EWCA Civ 9, [56]-[66]), the constitutional principle of judicial absention recognised in Belhaj v Straw (Section IV.2(c)(ii)) very arguably constitutes a "rule of law regarded as essential" in the UK's legal order such as to be capable of justifying application of the public policy exception (Case C-7/98, Krombach v Bamberski [2000] ECR I-1935, [37]).

222 Owusu v Jackson (n 182), [44]-[45]. See also Case C-116/02, Erich Gasser GmbH v MIS AT Srl [2003] ECR I-14963, [70]-[74]. 
Although they did not endorse the claimant's "incompatibility" argument founded on Owusu v Jackson, ${ }^{223}$ the judgment of Lords Walker and Collins in Lucasfilm v Ainsworth contains passages which support this line of reasoning. First, their Lordships note a connection, in terms of underlying justification, between the so called 'Mocambique rule' limiting the subject-matter jurisdiction of the English courts with respect to civil proceedings involving foreign land (including for trespass) and the "related, and more general principle, that the courts will not adjudicate upon the transactions of foreign sovereign states". ${ }^{224}$ Secondly, they express the view that the decision of the High Court of Australia in Potter v Broken Hill Pty Co Ltd, ${ }^{225}$ concerning the justiciability of claims founded on a foreign patent, "is a decision extending the act of state doctrine". 226 Thirdly, they conclude that, by reason of the UK's participation in the Brussels I regime, "the trespass aspect of the Mogambique rule has no application as regards land in other member states". ${ }^{227}$ Although their Lordships go no further than this, ${ }^{228}$ it is clear that they consider that the common law rule must here give way to the rules of jurisdiction within the Regulation (including the rule of domicile in what is now Art 4) to the extent that application of the former would be at odds with the narrowly construed rule of exclusive jurisdiction concerning rights in rem in immovable property in what is now Art 24(1). ${ }^{229}$ Fourthly, having refused to follow Potter v Broken Hill by concluding that "the foreign act of state doctrine ... should not today be regarded as an impediment to an action for infringement of foreign intellectual property rights", ${ }^{230}$ they go on to express the view that the Brussels I and Rome II Regulations "have undermined any argument that there is a substantial policy reason for the view that actions for the infringement of intellectual property rights cannot be brought outside the state in which they are granted or subsist". ${ }^{231}$ In so doing, they acknowledge the primacy to be given to the "general domicile rule of jurisdiction" within the Brussels I Regulation. ${ }^{232}$ Fifthly, in their summary of the earlier decision of the Court of Appeal in Pearce v Ove Arup, ${ }^{233}$ their Lordships do not question the proposition that, beyond the categories of exclusive jurisdiction created by the Brussels I regime, "the general rules of jurisdiction applied, and there was no room for an objection of non-justiciability". ${ }^{234}$ On their Lordships' own view of Potter v Broken Hill, however, the most credible basis for an objection of this kind was not an extension of the Mocambique rule (as the Court of Appeal reasoned in Pearce) but an extension of the act of state doctrine.

Having conceded this much ground, one might wonder whether Lord Walker and Collins, if pressed, would have found any satisfactory place in which to draw a line between those cases in which the common law principles requiring the English courts to restrain themselves in adjudicating upon foreign state acts do impair the effectiveness of the Brussels I Regulation and those in which they do not. Their

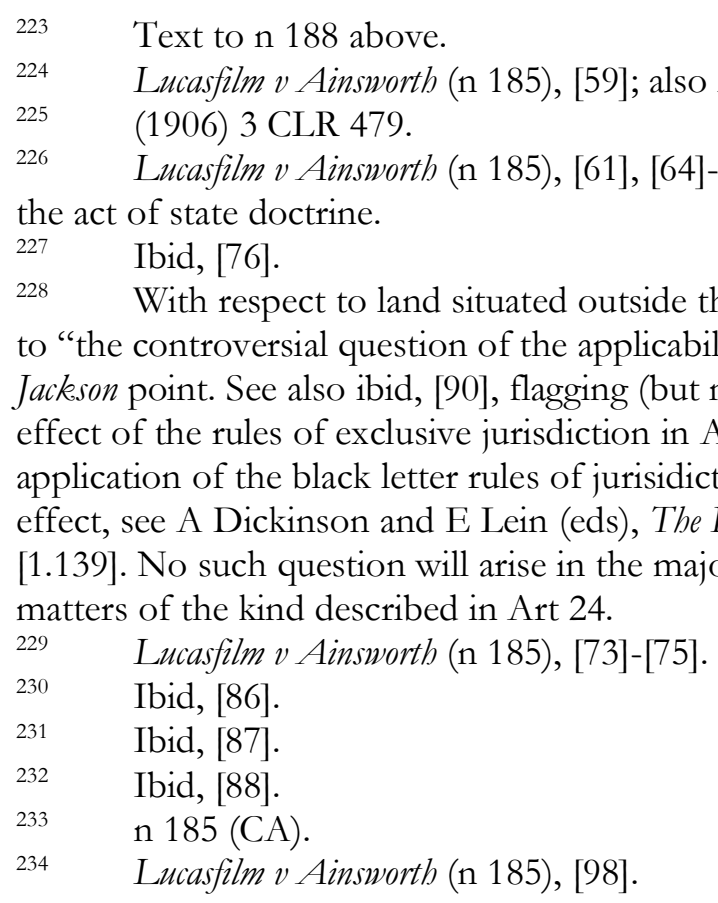


Lordships acknowledge in any event that, had they reached a different view as to the scope of the act of state doctrine in the case before them, it might have been necessary to refer the question of compatibility to the European Court. ${ }^{235}$ The issue is deserving of more detailed consideration should a suitable case arise. ${ }^{236}$

\section{Reappraising Dicey's Rule 3}

The foregoing analysis permits the following conclusions concerning the present formulation of Dicey's Rule 3, and the commentary upon that Rule. ${ }^{237}$

First, the Rule and commentary do not sufficiently account for the impact of the EU's private international law instruments in cases falling within the category of "civil and commercial matters". ${ }^{238}$ At any rate, the learned editors too readily reject the contention that the mandatory and exhaustive nature of the rules of jurisdiction, applicable law and recognition and enforcement of judgments within the Brussels I, Rome I and Rome II Regulations, coupled with principle of effectiveness under EU law, dictate that the rules and principles falling within the scope of the Rule will operate in such cases only at the margins, when those instruments incorporate rules of national law or permit derogation on public policy or other grounds. ${ }^{239}$

Secondly, the references to the Rule as involving the existence or exercise of "jurisdiction" underplay significantly the role played by choice of law doctrine. Indeed, although it is not the focus of this article, it is suggested that the first limb of Rule 3 is best understood as a choice of law rule covering the range of matters which, for reasons which have their roots in the constitution, fall within the exclusive dominion of English public law. ${ }^{240}$ In such cases, a foreign legal rule is incapable of creating a right of a kind that is actionable in the English courts.

Governmental acts affecting property require separate treatment. Here, the applicable English choice of law rule is superficially identical to the lex situs rule applied to private law property transactions. ${ }^{241}$ There are, however, important differences between the two, which reflect the additional constitutional/public law dimension. Most significantly, a title acquired under foreign legislation or as a result of a foreign governmental act will not, in general, be recognised by an English court even if the property was situated within the territory of the relevant state at the time that the legislation or act took effect, unless the state (or its successor in title) has reduced the property to its possession or taken equivalent steps to bring intangible property under its control. ${ }^{242}$ That is not a requirement when the proprietary claim is not founded on a governmental or other sovereign act. ${ }^{243}$ This difference in approach can also, it is suggested, be explained in terms of the exclusive dominion of English public law (including, for this purpose, laws concerning the compulsory acquisition and seizure of property): in general, under the UK's constitution, a public body may only take and retain possession of property if authorised to do so

\footnotetext{
235 Ibid, [113].

236 Recognising that the legal context will change following the UK's withdrawal from the EU (see n 14 above).

237 Section IV.1 above.

238 Section III above.

239 Section $\mathrm{V}$ above.

240 See text to nn 48-50 above.

241 Dicey, Morris \& Collins (n 15), Rule 137. cf Rules 132-135. See Y L Tan [2015] Singapore

Journal of Legal Studies 162.

242 Government of the Islamic Republic of Iran v Barakat Galleries Ltd (n 43), [143]-[148]. The Court held that this requirement was subject to an exception on public policy grounds in the case of cultural objects (ibid, [151]-[163]).

243 Ibid, [149]-[150].
} 
by an Act of Parliament. ${ }^{244}$ There is, however, no basis for applying this constitutional principle to a case in which the possession of property has been taken outside the United Kingdom: in that case, not only will the English courts recognise and give effect to a title acquired by legislation applicable in the place where the property was situated at the relevant time but also (semble) the English courts will not normally enquire as to the validity of the act of expropriation under the law of that place. ${ }^{245}$ The latter rule, which Lords Mance and Neuberger in Belhaj sought to justify on practical grounds relating to security of title, ${ }^{246}$ can equally be explained on the ground that questions concerning the proprietary effect of seizures of property by the state or by a public body are inherently constitutional in nature and are most suitably resolved within the framework of the constitutional order in which they arise.

Thirdly, with reference to the second limb of Dicey's Rule 3, analysis of the judgments in Belhaj and Rahmatullab (No 2) identifies two principal elements to the "act of state" doctrine under English law: a narrow, qualified principle of judicial abstention from adjudicating upon "issues of a sovereign, international or inter-state nature", ${ }^{247}$ and a mandatory rule of substantive law thirdly requires the English courts to treat as lawful acts performed abroad in the conduct of the UK's relations with other states or their subjects with the prior authority or subsequent ratification of the executive. ${ }^{248}$ These two elements are different in character and scope, both from each other and from the choice of law rules discussed above. It is highly desirable that they be kept apart in the minds of judges and practitioners. Rule 3 should be reformulated to reflect this separation, as well as the distinct character of the first and second limbs.

Finally, given that the principles comprised within the "act of state" doctrine will be of greatest practical significance in cases (such as those in Belhaj and Rahmatullah (No 2)) in which the claim is based upon rules of private law, it is important that the Rule and commentary should acknowledge that limits upon the English courts' constitutional competence must should be regarded as exceptional, demanding a very careful examination of the circumstances of the case with a view to establishing a valid reason for denying the possibility of a judicial remedy for the violation of private rights. ${ }^{249}$

2441 Bl Comm 134-135; Malone v Metropolitan Police Commissioner [1980] QB 49, 61-62 (Stephenson LJ); Monsanto v Tilly [2000] Environmental LR 313, 338-339 (Pill LJ). See also R (British American Tobacco (UK) Ltd v Secretary of State for Health [2016] EWHC 1169 (Admin), [2016] ETMR 38, [850]-[856].

245 Text to nn 90-95, 97-99 above, noting the reservations of Lord Mance and Lord Neuberger on this point (Belhaj v Straw (n 6), [65], [74] (Lord Mance), [137], [142]-[143] (Lord Neuberger)).

246 Ibid, [74] (Lord Mance), [142] (Lord Neuberger). See also ibid, [229] (Lord Sumption).

247 Text to nn 103-142 above.

248 This formulation adopts the approach of Lord Sumption, with which Lady Hale appears to concur, in Rahmatullah (No 2) (see text to nn 144-150, 159-160 above). By contrast, the approach of Lord Mance in that case recognises only the first principle of judicial abstention, albeit with differences in treatment as between UK and foreign sovereign acts (see text to nn 143, 151-158 above). 249 Shergill v Khaira (n 17), [42]; Belhaj v Straw (n 6), [8], [90], [107(v)] (Lord Mance), [145] (Lord Neuberger). See also R (Unison) v Lord Chancellor [2017] UKSC 51, [66]-[85] (Lord Reed). 